Article

\title{
Agronomic and Economic Evaluation of Autumn Planted Sugarcane under Different Planting Patterns with Lentil Intercropping
}

\author{
Mubashar Nadeem ${ }^{1, *(D)}$, Asif Tanveer ${ }^{1}$, Hardev Sandhu ${ }^{2, *}$, Saba Javed ${ }^{3}$, \\ Muhammad Ehsan Safdar ${ }^{4}$, Muhammad Ibrahim ${ }^{5}$, Muhammad Atif Shabir ${ }^{1}$, \\ Muhammad Sarwar ${ }^{1}$ and Usman Arshad ${ }^{6}$ \\ 1 Department of Agronomy, University of Agriculture, Faisalabad 38040, Pakistan; \\ drasiftanveeruaf@hotmail.com (A.T.); aatif.shabir@yahoo.com (M.A.S.); sarwar1406@gmail.com (M.S.) \\ 2 Everglades Research and Education Center, Institute of Food and Agricultural Sciences, \\ University of Florida, 3200 East Palm Beach Road, Belle Glade, FL 32611, USA \\ 3 Institute of Agriculture and Resource Economics, University of Agriculture, Faisalabad 38040, Pakistan; \\ sabasipra13@gmail.com \\ 4 Department of Agronomy, College of Agriculture, University of Sargodha, Sargodha 40100, Pakistan; \\ ehsan_safdar2002@yahoo.com \\ 5 Department of Agronomy, Faculty of Agricultural Sciences, Ghazi University, Dera Ghazi Khan 32200, \\ Pakistan; chibrahim@gudgk.edu.pk \\ 6 Department of Plant Pathology, University of Agriculture, Faisalabad 38040, Pakistan; \\ usman.jajja909@gmail.com \\ * Correspondence: mubasharuaf@hotmail.com (M.N.); hsandhu@ufl.edu (H.S.)
}

Received: 1 March 2020; Accepted: 21 April 2020; Published: 1 May 2020

\begin{abstract}
Proper sowing orientation and spacing are important factors for best crop growth. A field experiment was conducted to study the effect of different planting patterns with and without lentil intercropping on sugarcane growth and yield and farm economics. Each of these treatments were planted as sole crop and intercropped with lentil. Data were collected on plant cane and first ratoon crop. The maximum stripped cane yields (154.36 t/ha and $130.28 \mathrm{t} / \mathrm{ha}$ in plant and ratoon crop, respectively) were obtained from sugarcane planted at $120 \mathrm{~cm}$ trench planting both as sole as well as lentil intercropped. This treatment also attained $61 \%$ and $43 \%$ higher total sugar yields compared to traditional $60 \mathrm{~cm}$ single rows planting in plant and ratoon crops, respectively. Lentil intercropping did not have any significant effect on sugarcane yield, but trench planting at $120 \mathrm{~cm}$ with lentil intercropping had the highest lentil seed yield (598.0 in 2013-2014 and $629.8 \mathrm{~kg} \mathrm{ha}^{-1}$ in 2014-2015) along with maximum land equivalent ratio (1.40 and 1.37), net return (Rs.321254/ha), net field benefit (Rs.491703/ha) and benefit cost ratio (2.01). Sugarcane at $120 \mathrm{~cm}$ trench planting with lentil intercropping also outperformed other planting patterns in improving economic returns.
\end{abstract}

Keywords: pit plantation; planting patterns; ratoon crop; sowing techniques; sugarcane yield; quality

\section{Introduction}

Sugarcane plays a significant role in Pakistan's agriculture by producing sugar and other byproducts such as biofuel, fiber and press mud. It has a pivotal role in elevating the economic power of the farming community, as it contributes $3.6 \%$ value addition in agriculture and $0.7 \%$ in gross domestic products of Pakistan [1]. The harvestable yield potential of the current gene pool of sugarcane cultivars is more than $150 \mathrm{tha}^{-1}$; however, the national average yield is $60 \mathrm{tha}^{-1}$, which is below the genetic potential as well as the national average $\left(80-100 \mathrm{tha}^{-1}\right)$ of numerous advanced 
countries [2]. This yield gap must be bridged to match the sugar demands of an ever-increasing population. To increase national sugar production, sugarcane yield needs to be increased by making use of the latest production technology [3]. Low profitability resulting from high production cost, low gross income, and delayed payment to growers is also responsible for low sugarcane production in the country as farmers' interest in attaining higher yields is lost [4]. Therefore, production technology should be of such type that it may be able to increase the net income of sugarcane besides getting higher yield.

Planting geometry refers to the spatial distribution of plants over a specified field area. Appropriate planting geometry ensures the efficient and judicious use of the irrigation water. Desired level of seed germination, vigorous and healthy root and shoot growth and equal distribution in time and space are some of the key benefits realized by ensuring appropriate planting geometry. Altering the planting geometries not only influences the morphological characteristics; rather, all the physiological and quantitative parameters are influenced significantly as well [5]. Different planting geometries are being practiced by sugarcane growers of Pakistan, which attains same plant population [6]. Conventionally, sugarcane planting is planted at 60 to $90 \mathrm{~cm}$ row spacing, which increases initial plant population per unit area but it increases plant competition for sunlight, nutrients and water. Narrow spacing also obstructs several management operations necessary for good crop production, which resulted in crop lodging, and hence, the yield is considerably reduced [7]. On the other hand, wider spacing in the pit and trench planting method proved more suitable and effective compared to a conventional planting system because it maintains a high plant population throughout the growth, saves water (up to $20 \%$ ), prevents sugarcane lodging, eases earthing-up and inter-culture practices, and produces more net returns [7,8]. Observed higher stripped-cane yield (120.5 t/ha) in $120 \mathrm{~cm}$ row spacing than $60 \mathrm{~cm}$ row spacing $\left(68.42 \mathrm{t} \mathrm{ha}^{-1}\right)$. Similarly, an increased cane length $(3.0 \mathrm{~m})$ was observed in wider row spacing than narrow row spacing [9]. Trench planting is likely to provide enough space for post-planting management operations and reduce plant damage while maintaining optimum plant population.

The main aim of imposing such types of planting patterns is to overcome the limitations of older ones such as facilitation of inter-tillage practices, avoidance from lodging, maintaining optimum plant population and ease of irrigation, fertilizer, and plant protection [10]. Pit planting technique of sugarcane is a method with one of the highest potentials among methods used with space limitations. It was introduced in Pakistan as an efficient sowing method which promotes better germination, attains desirable plant population, and enhances sugar recovery [11]. It was pointed out that significantly higher cane yield of sugarcane could be achieved by planting sugarcane in $100 \mathrm{~cm} \times 100 \mathrm{~cm}$ pits that were $50 \mathrm{~cm}$ apart than the conventional method. The enhanced cane yield in pit planting is attributed to increased germination, leaf area index, and crop growth rate $[8,12,13]$.

The ratooning potential is the ability of sugarcane to re-sprout from left-over plant parts in the field after harvesting. From the farmer's point of view, it is considered the most desirable character of sugarcane cultivar [14]. This is due to fact that in case of ratoon crop, the cost of production is reduced up to $25-30 \%$ compared to fresh planted crop. In addition, there is considerable reduction in costs of land preparation, labor, irrigation quantity, and seed [15]. Ratoon crop also ensures an early supply of the sugarcane to the market; thus, benefitting the farming community economically as compared with the plant crop [16]. The area of Pakistan under ratoon crop of sugarcane is nearly $50 \%$ of its total cropped area, while about $25-30 \%$ of total sugarcane production is derived from ratoon crop [17]. Although ratoon crop attains $10-30 \%$ less cane yield compared to that achieved by the freshly planted crop, a yield gap of more than $35 \%$ still exists between its potential and realized yield [18]. The major factors responsible for the low yield of the ratoon crop are its inappropriate planting technique and poor management.

There are many ways to assure near future food safety and to boost the per unit crop yield in different farming systems; inter-cropping can be a viable option. It is a more efficient and eco-friendly method that results in enhanced production. Intercropping ensures efficient utilization of natural assets and harmonizes the effect of two or more crops grown simultaneously on same unit of land; 
thus, it is a very good option in the development of sustainable food production systems [19-21]. For developing countries such as Pakistan, intercropping can be introduced in the existing system of monocropping because it results in an increased farm income and better utilization of resources. The farming community can get great inspiration and higher net returns from this system [22].

Sugarcane is a relatively long-duration crop sown on wider spaced rows with slow initial growth. After emergence (5-6 weeks), it remains dormant for a period of 3-4 months due to low temperature. In order to drive benefits from its slow growth and make better use of resources, intercropping of some short duration crop (leguminous crop) can be explored. Lentil is one potentially viable option because it is a short-duration crop (3-4 months), fixes atmospheric nitrogen via symbiotic rhizobia in root nodules, and consequently, has, in rotation, the potential for maintaining soil fertility, and helps in controlling weeds.

More cane yield of the autumn planted sugarcane with lentil intercrop than sugarcane alone was reported by [23]. Other authors [24] observed a higher cane equivalent yield and the heaviest cane growth in a sugarcane + lentil system compared to sugarcane alone.

A comprehensive study was planned and executed for getting higher sugarcane yield. The specific objective of the study was to compare the different planting patterns, namely, single row, double and trench planting, pit plantation techniques, and ratoon crop with and without lentil intercropping aimed at getting higher cane yield, quality, and net economic returns under agro-ecological conditions of Punjab, Pakistan. We hypothesized trench planting of sugarcane and its intercropping with lentil will improve the growth and yield of both the crops.

\section{Materials and Methods}

\subsection{Site and Soil}

The field studies were carried out consecutively for two years 2013-2015 and 2015-2016 at Agronomy farm, University of Agriculture, Faisalabad, Pakistan. The soil is alluvial in nature and the area is canal irrigated. The geographic location of Faisalabad is $31.5^{\circ} \mathrm{N}$ latitude and $73^{\circ} \mathrm{E}$ longitude, with $184.4 \mathrm{~m}$ altitude above sea level. The weather is considered semi-arid with very hot and humid summers and cool dry winters. The summer season starts from the month of April, which lasts up to October, whereas the hottest months of the years are May to July. December to February are known as the coldest months in Pakistan.

Prior to the start of each experiment, a composite soil sample to 0-30 $\mathrm{cm}$ depth from the experimental site was analyzed for various physicochemical characteristics of the soil. For analysis of nitrogen $(\mathrm{N})$, phosphorous $(\mathrm{P})$ and potash $(\mathrm{K})$ soil sampling was done after the harvest of the crop. The analysis was carried out in the Institute of Soil and Environmental Sciences (ISES) and results are given in Table 1. The soil analysis showed that the soil of the trial site was sandy loam, slightly alkaline, and highly deficient in nitrogen and phosphorus.

Table 1. Soil analysis of the experimental soil.

\begin{tabular}{ccc}
\hline Soil Characteristics & 2013-2015 & 2015-2016 \\
\hline & A. Physical characteristics & \\
\hline Sand \% & 63.12 & 61.85 \\
Silt \% & 19.75 & 16.39 \\
Clay \% & 19.29 & 20.95 \\
\hline & 7.80 \\
\hline pH & B. Chemical analysis \\
$\mathrm{EC}_{\mathrm{e}}\left(\mathrm{dSm}^{-1}\right)$ & 0.79 & 7.85 \\
Organic matter $(\%)_{\text {Available } \mathrm{N}(\%)}$ & 0.041 & 1.19 \\
Available Phosphorus $\mathrm{P}_{2} \mathrm{O}_{5}(\mathrm{ppm})$ & 6.99 & 0.80 \\
Available Potassium $\mathrm{K}_{2} \mathrm{O}(\mathrm{ppm})$ & 140 & 6.043 \\
& & 135 \\
\hline
\end{tabular}




\subsection{Meteorological Data}

Agricultural Meteorology Cell, Agriculture University, provided the measured metrological data. Data are presented in Figure 1. Total rainfall during the growing period of the freshly-planted crop was $378 \mathrm{~mm}$, while that of ratoon crop was $413 \mathrm{~mm}$.

(a)
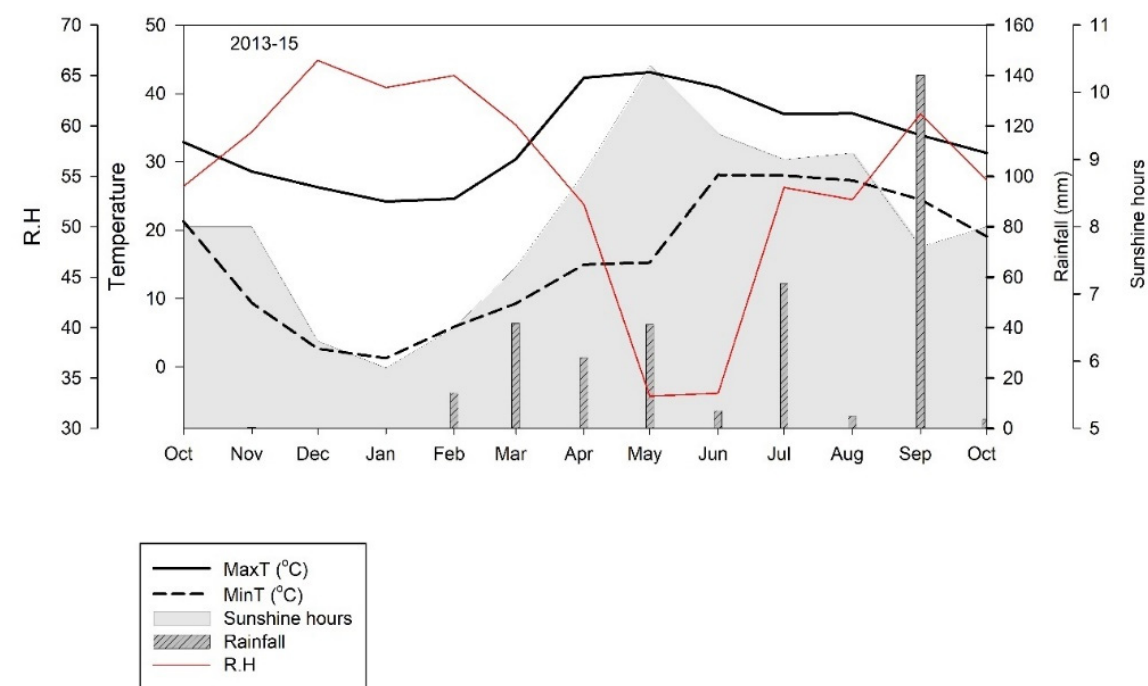

(b)
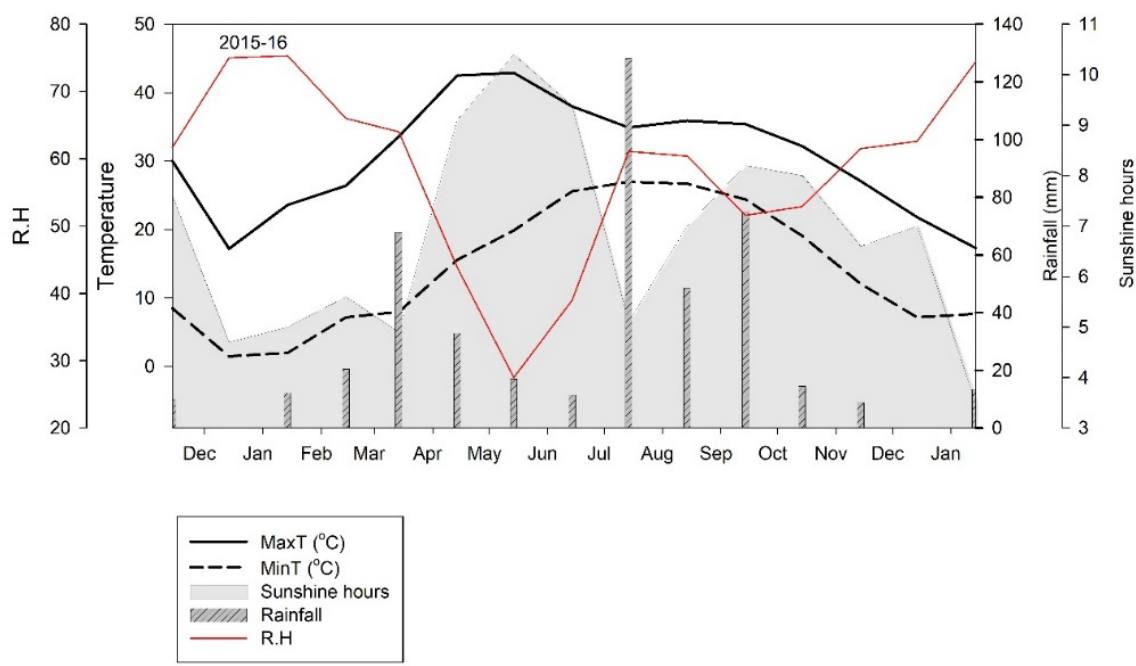

Figure 1. Meteorological data during. (a) Plant crop and (b) ratoon crop seasons of sugarcane.

\subsection{Experimental Design and Treatments}

The experiment was laid out in randomized complete block design with split plot arrangement having four replications. Treatments included seven planting patterns of sugarcane allotted to sub-plots in both plant cane and ratoon crops. In pit planting, the $90 \mathrm{~cm}$ diameter pits were established at 45, 60, 75 , and $90 \mathrm{~cm}$ row-to-row as well as plant-to-plant spacing in treatments P1, P2, P3, and P4, respectively. In treatment $\mathrm{P} 5$, sugarcane was planted in single rows with $60 \mathrm{~cm}$ row-to-row spacing. In treatment P6, there were twin rows or double rows with $90 \mathrm{~cm}$ row-to-row spacing. Treatment P7 consisted of trench 
planting with $120 \mathrm{~cm}$ row to row distance with double rows of double budded setts placed at $20-25 \mathrm{~cm}$ depth. The plot size was $4.2 \mathrm{~m} \times 9 \mathrm{~m}$ in P1, $4.5 \mathrm{~m} \times 9 \mathrm{~m}$ in P2, $4.95 \mathrm{~m} \times 9 \mathrm{~m}$ in P3, $4.95 \mathrm{~m} \times 9 \mathrm{~m}$ in P4, $4.80 \mathrm{~m} \times 9 \mathrm{~m}$ in P5, $4.80 \mathrm{~m} \times 9 \mathrm{~m}$ in P6 and $7.2 \mathrm{~m} \times 9 \mathrm{~m}$ in P7. Each of these treatments was planted as sole as well as intercropped with lentil that acted as the main plots. Lentil was intercropped in between the empty spaces of sugarcane rows/pits of each treatment at $30 \mathrm{~cm}$ distance (Figure 2).

\subsection{Crop Husbandry}

The field preparation in case of single, double, and trench planting methods was carried out using the standard procedure of ploughing, cultivation and levelling. However, in the case of pit plantation, a tractor-mounted post-hole digger was used to dig round pits of $60 \mathrm{~cm}$ depth in zero tilled soil. The $90 \mathrm{~cm}$ double rows planting and $120 \mathrm{~cm}$ trenches were made with the help of a sugarcane ridger. Afterwards, digging pits were again filled with the same soil to a depth of $45 \mathrm{~cm}$. Sugarcane's variety CPF-247 was selected as a test variety for both years of experiment. Sowing was done on 14th of September 2013 and lentil was intercropped on 25th October 2013. However, in case of ratoon crop, lentil was sown just after the harvesting of plant crop. Lentil variety (NIAB Masoor-2006) was used as an intercrop. In different planting methods according to the space available, different number of lentil rows was sown, i.e., in $45 \mathrm{~cm}$-spaced round pits with one row of lentil, $60 \mathrm{~cm}$-spaced round pits with two rows of lentil, $75 \mathrm{~cm}$-spaced round pits with two rows of lentil, $90 \mathrm{~cm}$-spaced round pits with three rows of lentil, $60 \mathrm{~cm}$-single row planting (conventional method) with one row of lentil, $90 \mathrm{~cm}$-double row planting with two rows of lentil, and $120 \mathrm{~cm}$-trench planting with four rows of lentil that were in between the empty spaces of sugarcane, while Lentil alone was planted in $30 \mathrm{~cm}$-spaced single rows with 12 rows.

The $120 \mathrm{~cm}$ trenches, $90 \mathrm{~cm}$ double rows planting, and $60 \mathrm{~cm}$ single rows plantation of sugarcane were given two manual hoeings and one earthing-up. The first two hoeings were done on 28th November and 7th February, respectively. Earthing-up was done in the middle of March. In ratoon crop, earthing up was done by the end of May. The pit-planted sugarcane crop was not earthed-up at any stage. However, one hoeing was done two months after planting to control weeds growing in the space between the pits. The pits were inter-connected with one another through small water channels to design a basin irrigation system. Irrigation and fertilizer application were restricted only to pits. A total of 20 irrigations each of $10 \mathrm{~cm}$ depth were applied to sugarcane, while lentil crop was given only one-two irrigations during the whole growing period. The total amount of irrigation water applied to the plant crop was $1977 \mathrm{~mm}$, while to ratoon crop it was $1950 \mathrm{~mm}$. The N, P, and K were applied at a rate of 165,110 , and $110 \mathrm{~kg} \mathrm{ha}^{-1}$ in the form of urea, di-ammonium phosphate, and sulfate of potash, respectively. However, ratoon crop was fertilized at 30\% higher amounts compared to the first-year fresh planted crop. Insect-pests were controlled through chlorpyriphos at $5 \mathrm{~L} / \mathrm{h}$ a with first irrigation. Plant crop of sugarcane was harvested on 30th November 2014, while ratoon crop of sugarcane was harvested on January 15th 2016. Lentil harvesting was done on 21st of March 2014 and 2nd April 2015.

\subsection{Observations}

Sugarcane growth, i.e., leaf area index (LAI), leaf area duration (LAD), crop growth rate (CGR), net assimilation rate (NAR), and total dry matter (TDM), yield and yield related traits, i.e., number of millable canes $\mathrm{m}^{-2}$, plant height, cane length, cane diameter, and stripped cane yield, and total sugar yield, lentil yield and yield components (1000-seed weight, biological yield, seed yield, harvest index), and land equivalent ratio were recorded through their standard procedures.

LAI: With the help of leaf area meter ( $\Delta \mathrm{T}$ area meter MK2) leaf area of green laminae was recorded. Following formula was used for its calculation:

$$
L A I=\frac{\text { Laef area of crop plants }}{\text { Land area of crop plants }}
$$


LAD (Days): The authors in [23] proposed the following formula for computing LAD:

$$
L A D=\left[\left(L A I_{1}+L A I_{2}\right) \times \frac{\left(T_{2}-T_{1}\right)}{2}\right] \text { days }
$$

where $\mathrm{LAI}_{1}=$ Leaf area index at $\mathrm{t}_{1}, \mathrm{LAI}_{2}=$ Leaf area index at $\mathrm{t}_{2}, \mathrm{~T}_{1}=$ Time of first observation, $\mathrm{T}_{2}=$ Time of second observation, $\mathrm{T}_{1}$ and $\mathrm{T}_{2}$ are with 30 days interval, while the following 60 days of planting were recorded.

CGR $\left(\mathrm{g} \mathrm{m}^{-2}\right.$ day $\left.^{-1}\right)$ : The authors in [25] projected the CGR formula as follows:

$$
C G R=\frac{\left(W_{2}-W_{1}\right)}{\left(T_{2}-T_{1}\right)}
$$

where $W_{1}$ is considered the plant dry weight at time $t_{1}, W_{2}$ is known as plant dry weight during the time $t_{2} . T_{1}$ and $T_{2}$ are the harvest time for the 1 st and 2 nd time, respectively. $W_{2}$ and $W_{1}$ are the total dry weights harvested at time $\mathrm{T}_{1}$ and $\mathrm{T}_{2}$, respectively; first data were collected at 60 days after planting.

NAR $\left(\mathrm{g} \mathrm{m}^{-2}\right.$ day $\left.^{-1}\right)$ : NAR was determined by using the formula proposed by the authors in [25]:

$$
N A R=\frac{T D M}{L A D}
$$

where $\mathrm{TDM}=$ Total dry matter, $\mathrm{LAD}=$ Leaf area duration

TDM (t/ha): After a 30-day interval, plant sampling was carried out on a random basis from each experimental unit. To estimate the fresh weight, plants were separated into leaves, stem, and trash. To determine the dry weight, a $10 \mathrm{~g}$ plant sample was taken from each portion after drying at $65^{\circ} \mathrm{C}$. TDM was ascertained in ( $\mathrm{g}$ ) and converted into $\mathrm{t} / \mathrm{ha}$ after adding the dry weights of the leaves, stem, and trash.

Number of millable canes $/ \mathrm{m}^{2}$ : From each experimental unit at harvest, the number of millable canes was tallied and then calculated in $\mathrm{m}^{-2}$ area.

Plant height $(\mathrm{cm})$ : At harvest, 10 stripped canes from each treatment were collected. From the plant base to the base of top visible dewlap (TVD), the leaf plant height of each plant was calculated. Then, their average was calculated.

Cane length $(\mathrm{cm})$ : Ten randomly selected stripped canes were measured and their average values were recorded.

Cane diameter $(\mathrm{cm})$ : Ten randomly stripped canes were collected at the time of harvesting. The top, middle, and base of the cane was used for the diameter determination with a vernier caliper and then averaged.

Stripped cane yield ( $t / h a)$ : All stripped canes of each plot were weighed, and then the number was transformed to $\mathrm{t} / \mathrm{ha}$.

Total sugar yield ( $\mathrm{t} / \mathrm{ha})$ : Sugar yield ( $\mathrm{t} / \mathrm{ha}$ ) was calculated using the following formula:

$$
\text { Sugar yield }(t / h a)=\frac{\text { Stripped cane yield }(t / h a)}{100} \times \operatorname{CCS} \%
$$

The commercial cane sugar (CCS\%) was calculated through formula of [26]:

$$
C C S=\frac{3 P}{2}\left[1-\frac{(F+5)}{100}\right]-\frac{1}{2} B\left[1-\frac{(F+3)}{100}\right]
$$

where $\mathrm{P}$ is the percentage of pol in juice, $\mathrm{B}$ is the percentage of brix in juice, and $\mathrm{F}$ is the percentage of fiber in juice $(12.5 \%)$

Land equivalent ratio: The authors in [27] proposed the formula for computing the term land equivalent ratio (LER):

$$
\mathrm{LER}=(\mathrm{Yab} / \mathrm{Yaa})+(\mathrm{Yba} / \mathrm{Ybb}),
$$


where Yaa $=$ pure stand yield of crop a (sugarcane), Ybb = pure stand yield of crop b (lentil), $\mathrm{Yab}=$ intercrop yield of crop a (sugarcane), Yba = intercrop yield of crop b (lentil).

\subsection{Economic Analysis}

After deduction of the gross investment from the gross field benefits, the net filed benefit (NFB) was calculated [28]. Gross benefit refers to the gross income generated from the main and by-products from component crops in an intercropping system. The total variable cost (PKR Rs./ha) was attained by computing the total variable cost of the production of sugarcane and intercrop in each treatment. The benefit-cost ratio (BCR) was determined through dividing the gross income with the total cost of production. The marginal analysis comprises the dominance analysis (DA) and the marginal rate of return (MRR). In DA, the treatments were arranged in increasing variable cost order. A treatment was dominant (D) when its variable costs was more than the previous treatment, but its NFB was lower or equal [28]. MRR \% is the marginal net field benefits (MNB) of the variation in NFB divided by the marginal costs (MC), i.e., the variation in costs expressed as a Percentage. MRR was calculated using the formula given by [26]:

$$
\operatorname{MRR}(\%)=\frac{\mathrm{MNB}}{\mathrm{MC}} \times 100
$$

\subsection{Statistical Analysis}

Fisher's analysis of variance was used for statistically analysis of collected data and for comparison of differences among treatment means; a least significant difference (LSD) test was used at 5\% probability [29]. Statistics 10 (Tallahassee, FL 32317) was used for the determination of statistical difference.
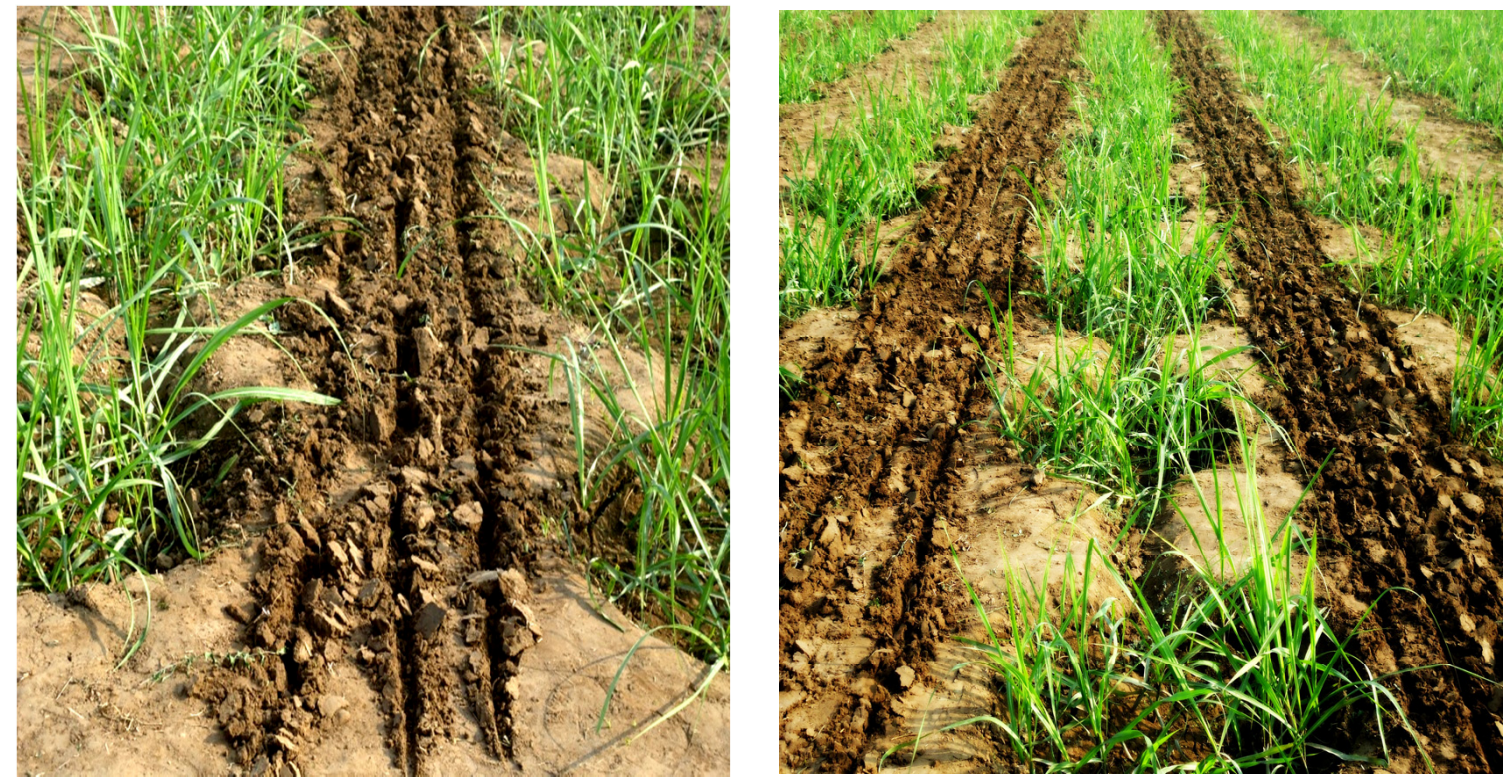

Figure 2. Cont. 

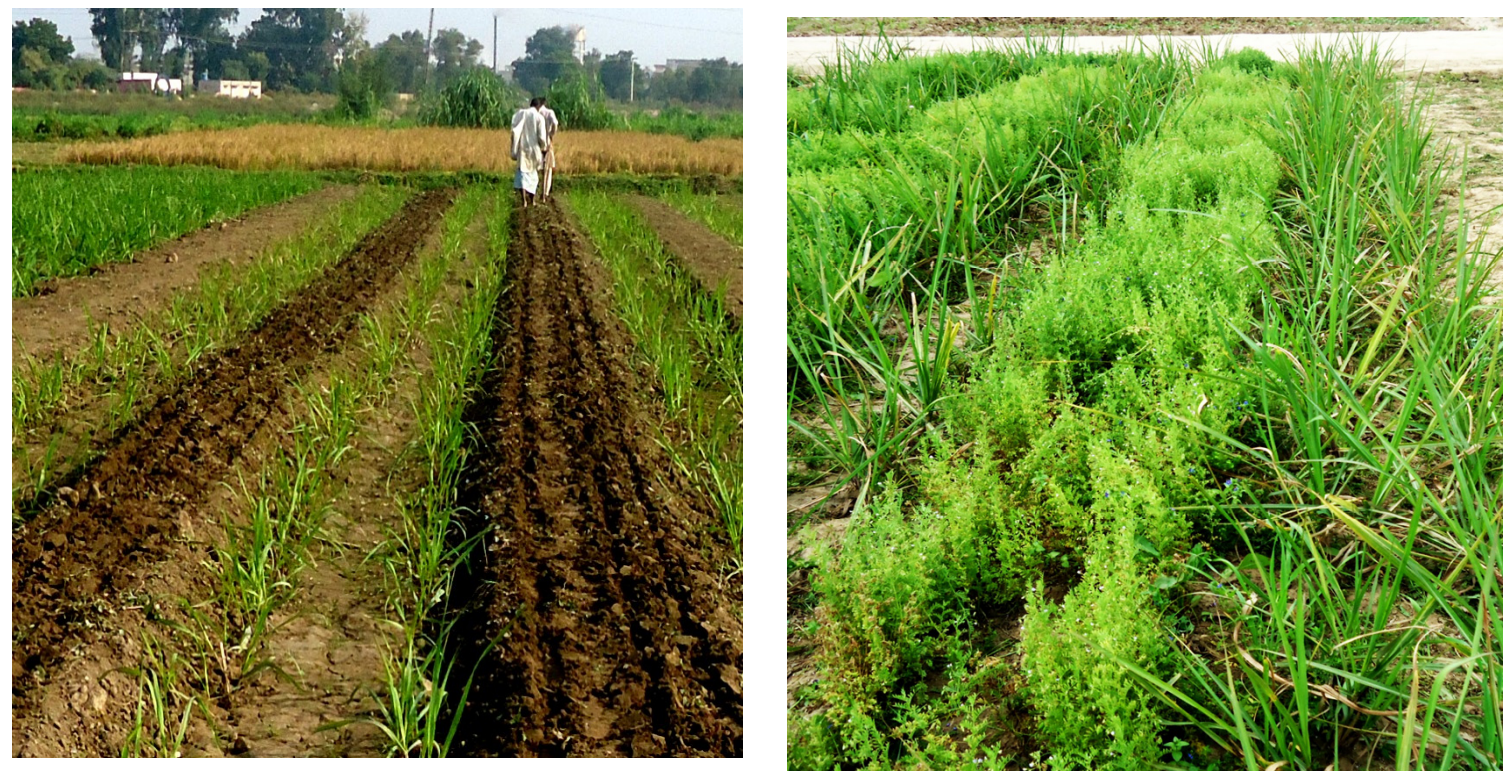

Figure 2. Lentil intercropping in sugarcane.

\section{Results}

\subsection{Sugarcane Growth}

Different planting patterns of sugarcane showed a significant effect on growth parameters of sugarcane planted alone and intercropped with lentil presented in (Figures 3-7). In plant crop, sugarcane sown in $120 \mathrm{~cm}$ trench planting (sugarcane alone) attained the highest LAI (8.97), LAD (1346 days), CGR (12.42 $\left.\mathrm{g} \mathrm{m}^{-2} \mathrm{day}^{-1}\right)$, NAR (3.15 $\mathrm{g} \mathrm{m}^{-2}$ day $\left.^{-1}\right)$, and TDM (34.64 $\left.\mathrm{t} \mathrm{ha}^{-1}\right)$. The same planting geometry with lentil intercropping as well as $45 \mathrm{~cm}$ pits with $90 \mathrm{~cm}$ diameter, $60 \mathrm{~cm}$ pits with $90 \mathrm{~cm}$ diameter, and $75 \mathrm{~cm}$ pits with $90 \mathrm{~cm}$ diameter both in sugarcane planted alone and intercropped with lentil gave similar results regarding the growth parameters of sugarcane. In contrast, the minimum values of these parameters were recorded from the treatment where sugarcane was planted in $60 \mathrm{~cm}$ single rows with and without lentil as an intercrop.

In ratoon crop, the maximum LAI (7.88), LAD (1160 days), CGR (11.11 $\left.\mathrm{g} \mathrm{m}^{-2} \mathrm{day}^{-1}\right)$, NAR $\left(2.75 \mathrm{~g} \mathrm{~m}^{-2} \mathrm{day}^{-1}\right)$, and TDM $\left(29.62 \mathrm{t} \mathrm{ha}^{-1}\right)$ were recorded in trench planting at $120 \mathrm{~cm}$ (sugarcane alone), followed by $45 \mathrm{~cm}$ pits with $90 \mathrm{~cm}$ diameter, $120 \mathrm{~cm}$ trench planting with lentil intercrop, and $60 \mathrm{~cm}$ pits with $90 \mathrm{~cm}$ diameter. Sugarcane planted in $60 \mathrm{~cm}$ single rows planting + lentil as an intercrop and sugarcane sown in $60 \mathrm{~cm}$ apart as sole crop showed the minimum values of these parameters. 
(a)

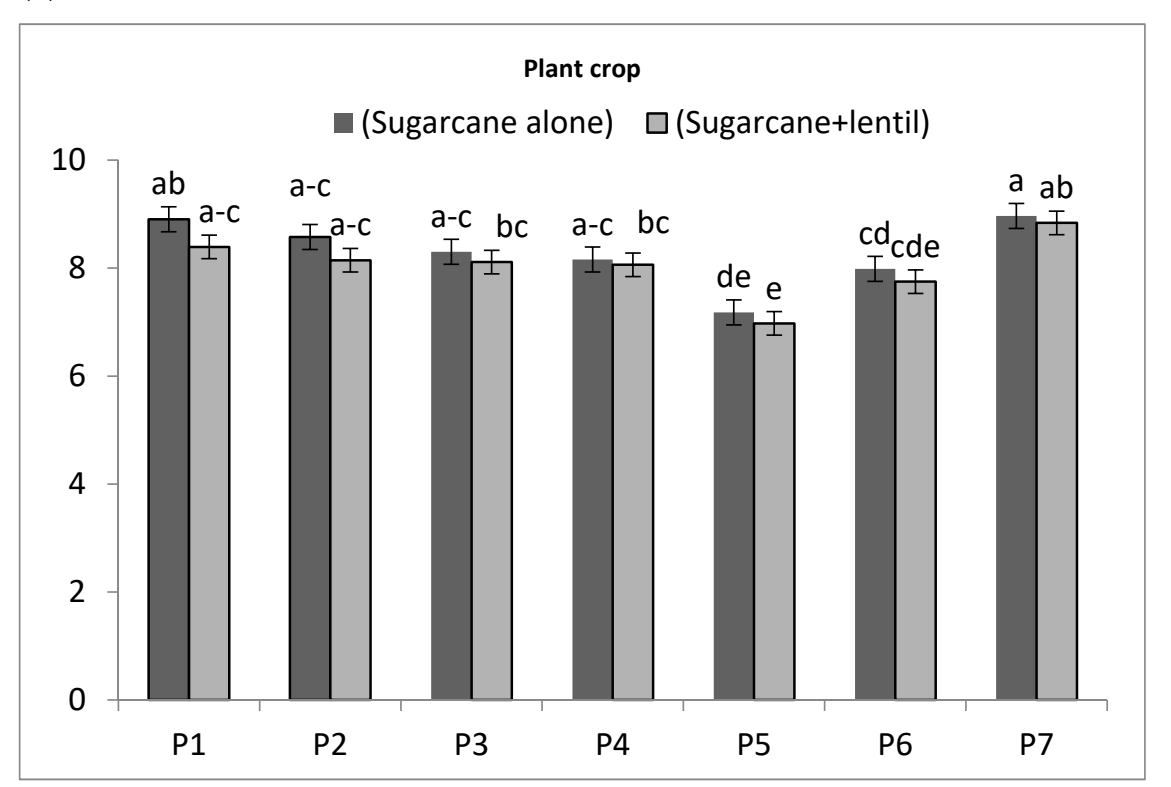

(b)

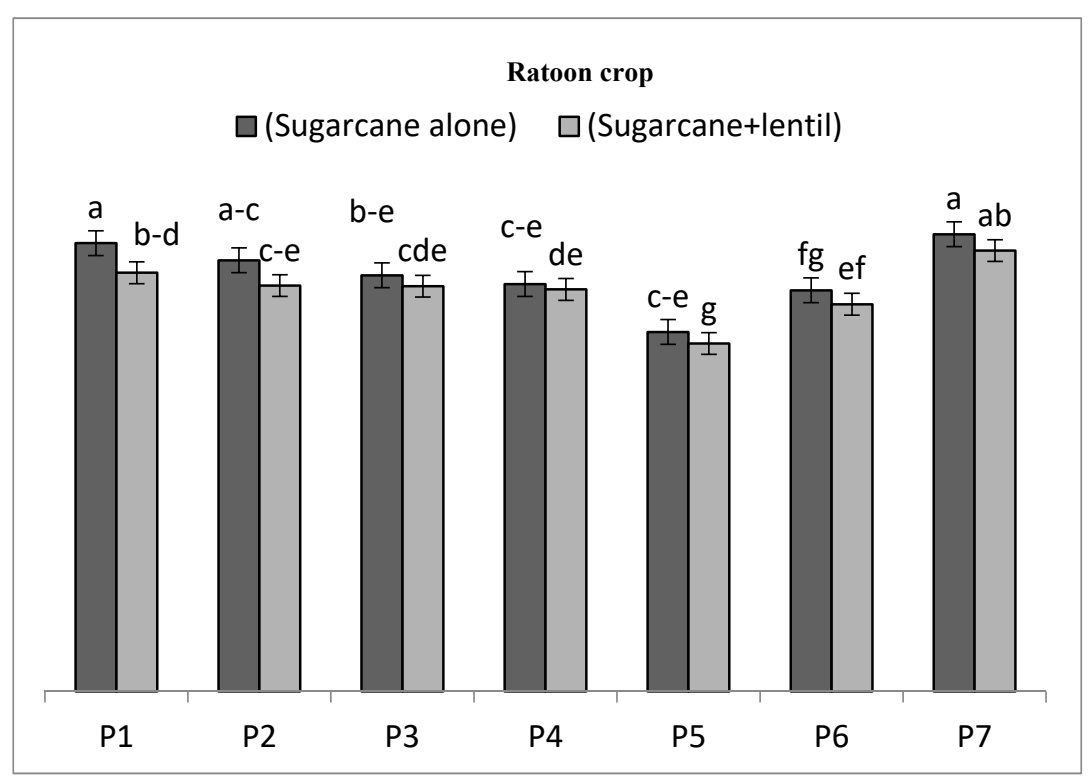

Figure 3. Leaf area index of sugarcane as influenced by various planting patterns and lentil intercropping in (a) Plant crop and (b) ratoon crop. $\mathrm{P}_{1}$ : $45 \mathrm{~cm}$ pits with $90 \mathrm{~cm}$ diameter, $\mathrm{P}_{2}: 60 \mathrm{~cm}$ pits with $90 \mathrm{~cm}$ diameter, $\mathrm{P}_{3}: 75 \mathrm{~cm}$ pits with $90 \mathrm{~cm}$ diameter, $\mathrm{P}_{4}: 90 \mathrm{~cm}$ pits with $90 \mathrm{~cm}$ diameter, $\mathrm{P}_{5}: 60 \mathrm{~cm}$ single rows planting, $\mathrm{P}_{6}: 90 \mathrm{~cm}$ double rows planting, $\mathrm{P}_{7}$ : Trench planting at $120 \mathrm{~cm}$. Any two means not sharing a common letter(s) differ significantly at $5 \%$ probability. 
(a)

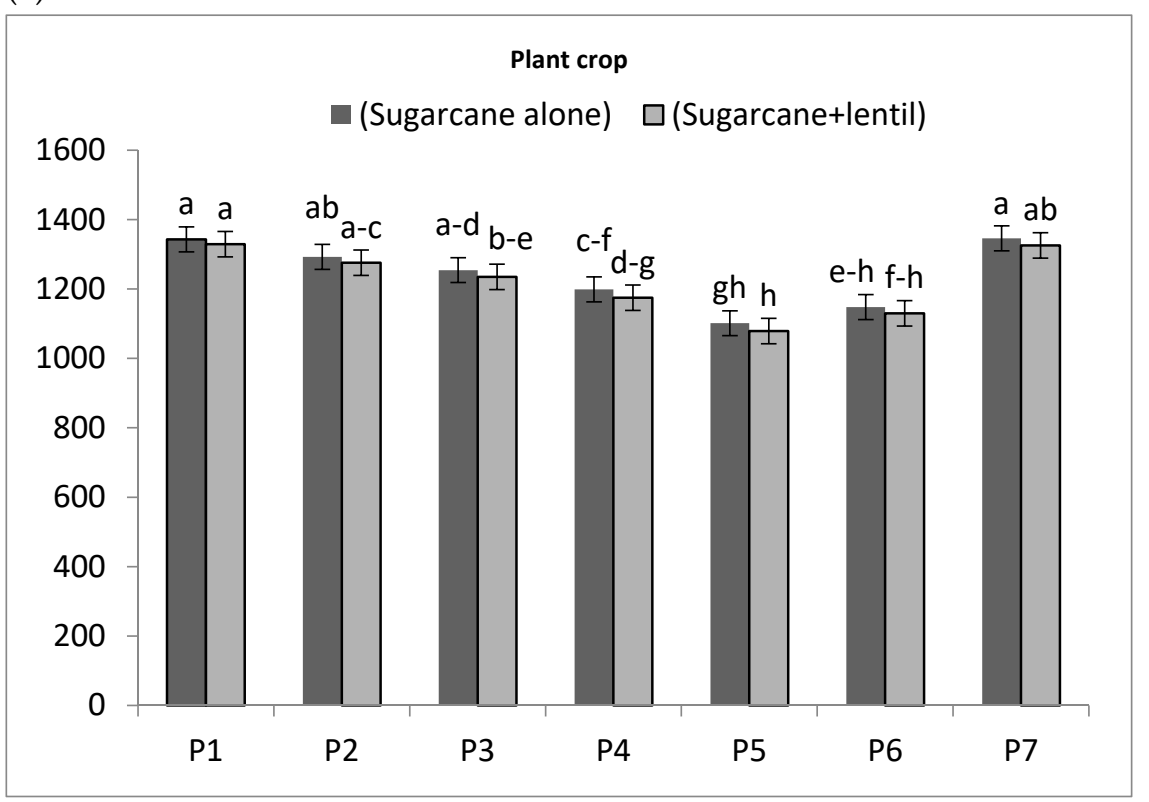

(b)

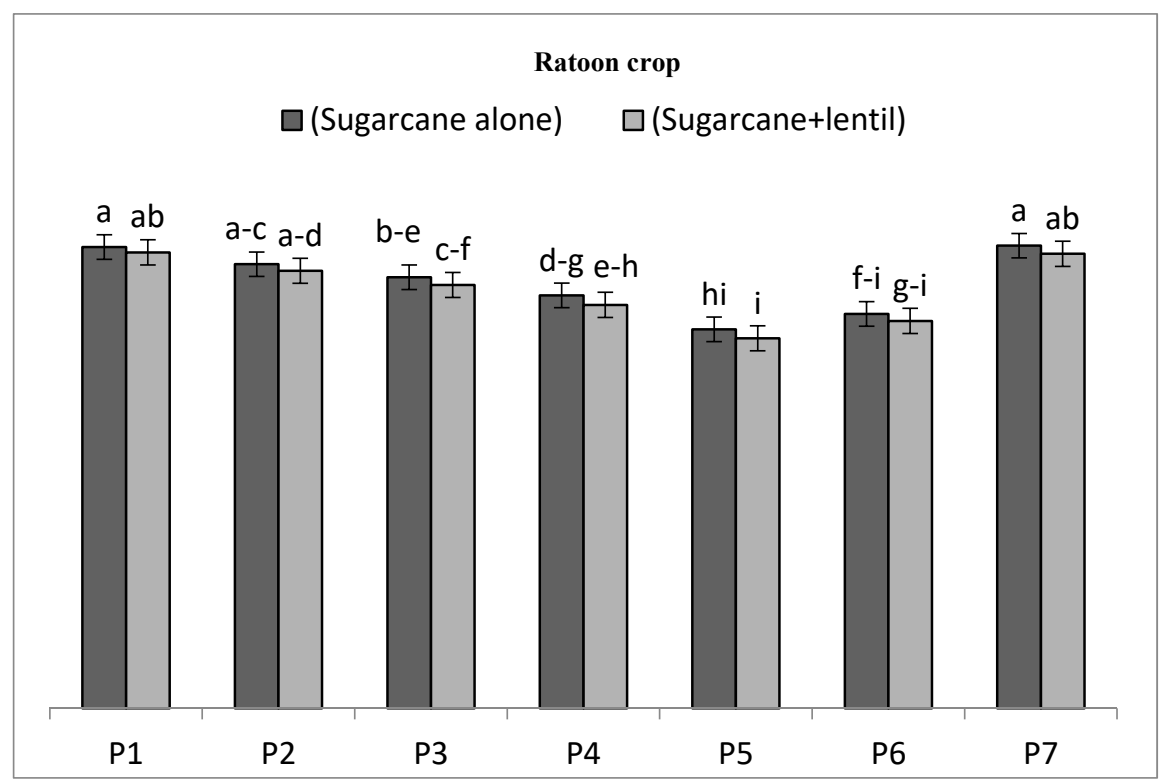

Figure 4. Leaf Area Duration (Days) of sugarcane as influenced by various planting patterns and lentil intercropping in (a) Plant crop and (b) ratoon crop. $\mathrm{P}_{1}$ : $45 \mathrm{~cm}$ pits with $90 \mathrm{~cm}$ diameter, $\mathrm{P}_{2}: 60 \mathrm{~cm}$ pits with $90 \mathrm{~cm}$ diameter, $\mathrm{P}_{3}: 75 \mathrm{~cm}$ pits with $90 \mathrm{~cm}$ diameter, $\mathrm{P}_{4}: 90 \mathrm{~cm}$ pits with $90 \mathrm{~cm}$ diameter, $\mathrm{P}_{5}: 60 \mathrm{~cm}$ single rows planting, $\mathrm{P}_{6}$ : $90 \mathrm{~cm}$ double rows planting, $\mathrm{P}_{7}$ : Trench planting at $120 \mathrm{~cm}$. Any two means not sharing a common letter(s) differ significantly at $5 \%$ probability. 
(a)

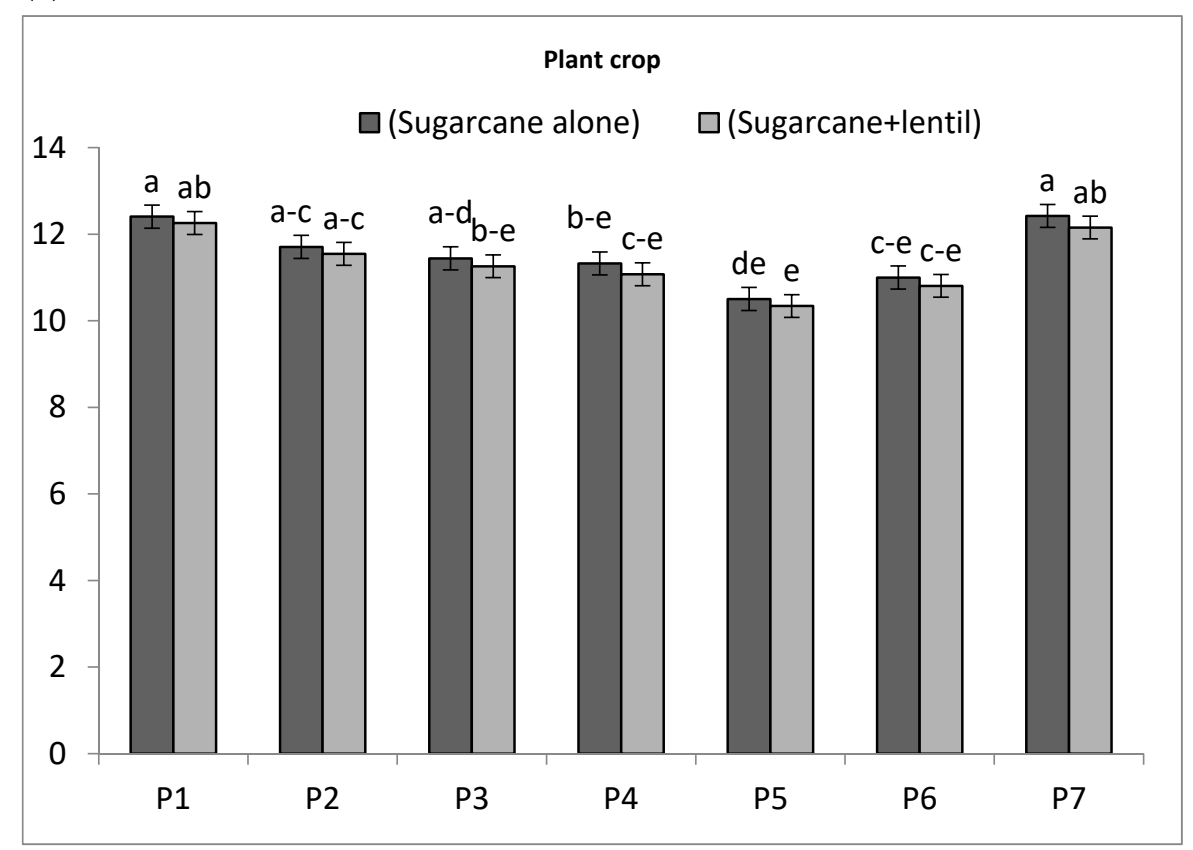

(b)

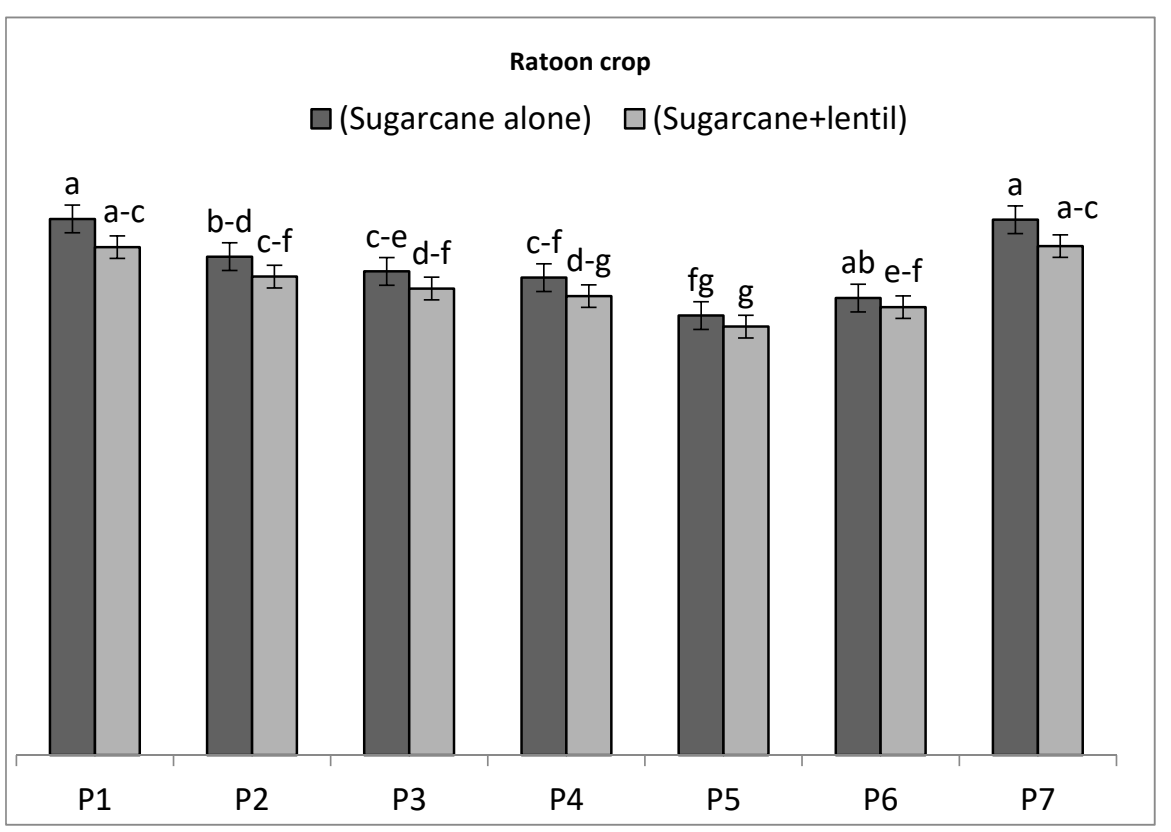

Figure 5. Crop growth rate $\left(\mathrm{g} \mathrm{m}^{-2}\right.$ day $\left.^{-1}\right)$ of sugarcane as influenced by various planting patterns and lentil intercropping in (a) Plant crop and (b) ratoon crop. $\mathrm{P}_{1}: 45 \mathrm{~cm}$ pits with $90 \mathrm{~cm}$ diameter, $\mathrm{P}_{2}: 60 \mathrm{~cm}$ pits with $90 \mathrm{~cm}$ diameter, $\mathrm{P}_{3}: 75 \mathrm{~cm}$ pits with $90 \mathrm{~cm}$ diameter, $\mathrm{P}_{4}: 90 \mathrm{~cm}$ pits with $90 \mathrm{~cm}$ diameter, $\mathrm{P}_{5}: 60 \mathrm{~cm}$ single rows planting, $\mathrm{P}_{6}: 90 \mathrm{~cm}$ double rows planting, $\mathrm{P}_{7}$ : Trench planting at $120 \mathrm{~cm}$. Any two means not sharing a common letter(s) differ significantly at $5 \%$ probability. 
(a)

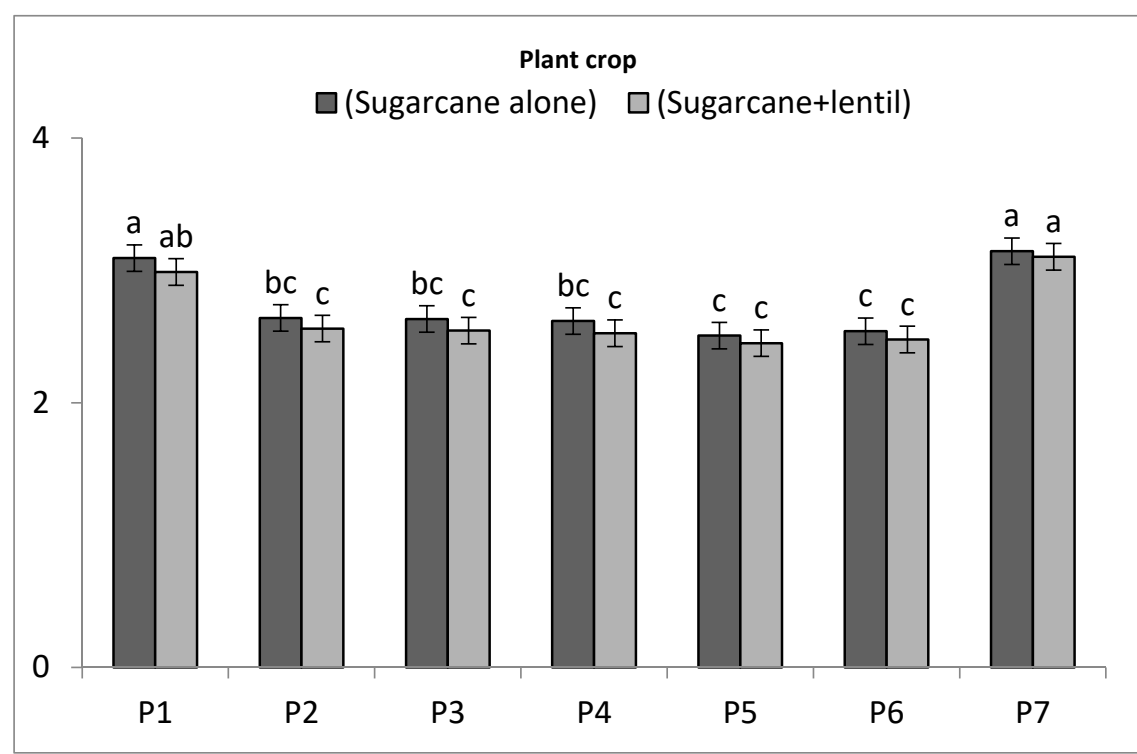

(b)

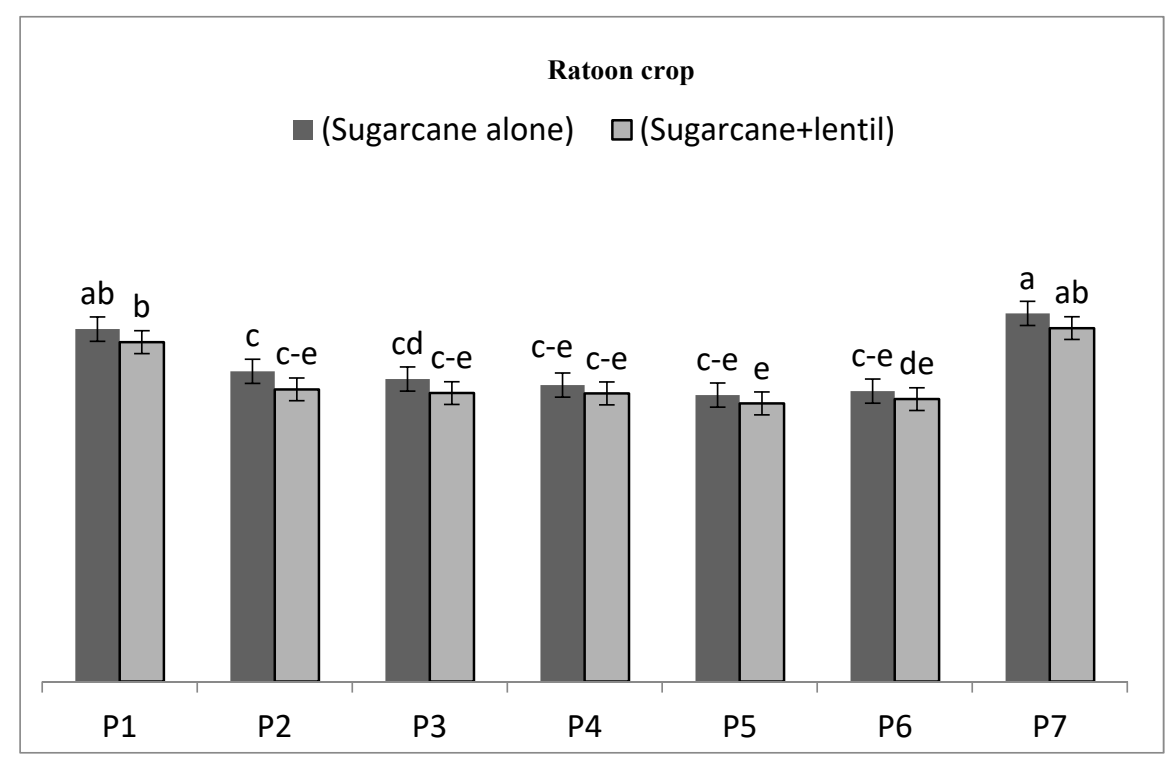

Figure 6. Net assimilation rate $\left(\mathrm{g} \mathrm{m}^{-2} \mathrm{day}^{-1}\right)$ of sugarcane as influenced by various planting patterns and lentil intercropping in (a) Plant crop and (b) ratoon crop. $P_{1}: 45 \mathrm{~cm}$ pits with $90 \mathrm{~cm}$ diameter, $\mathrm{P}_{2}: 60 \mathrm{~cm}$ pits with $90 \mathrm{~cm}$ diameter, $\mathrm{P}_{3}: 75 \mathrm{~cm}$ pits with $90 \mathrm{~cm}$ diameter, $\mathrm{P}_{4}: 90 \mathrm{~cm}$ pits with $90 \mathrm{~cm}$ diameter, $\mathrm{P}_{5}: 60 \mathrm{~cm}$ single rows planting, $\mathrm{P}_{6}: 90 \mathrm{~cm}$ double rows planting, $\mathrm{P}_{7}$ : Trench planting at $120 \mathrm{~cm}$. Any two means not sharing a common letter(s) differ significantly at $5 \%$ probability. 
(a)

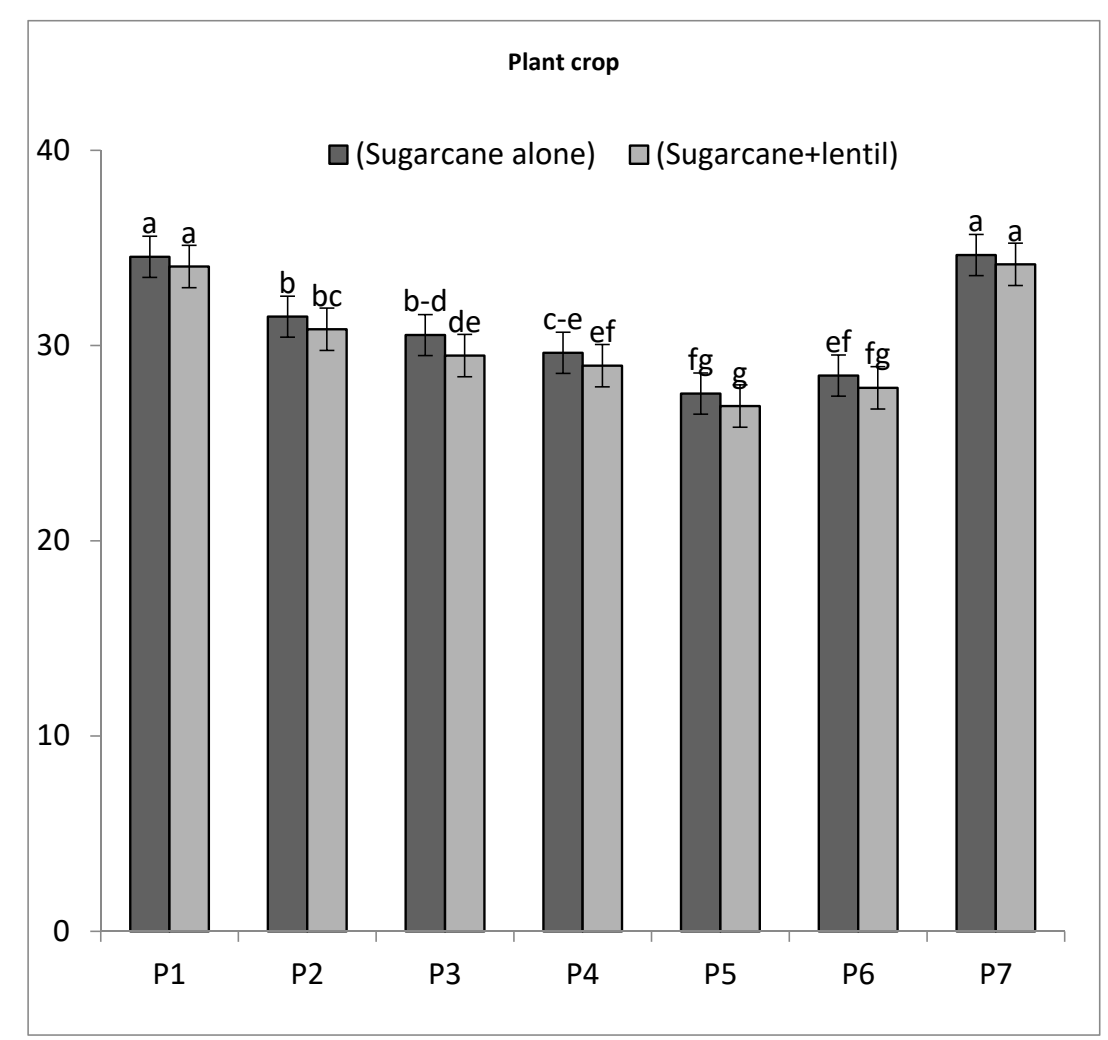

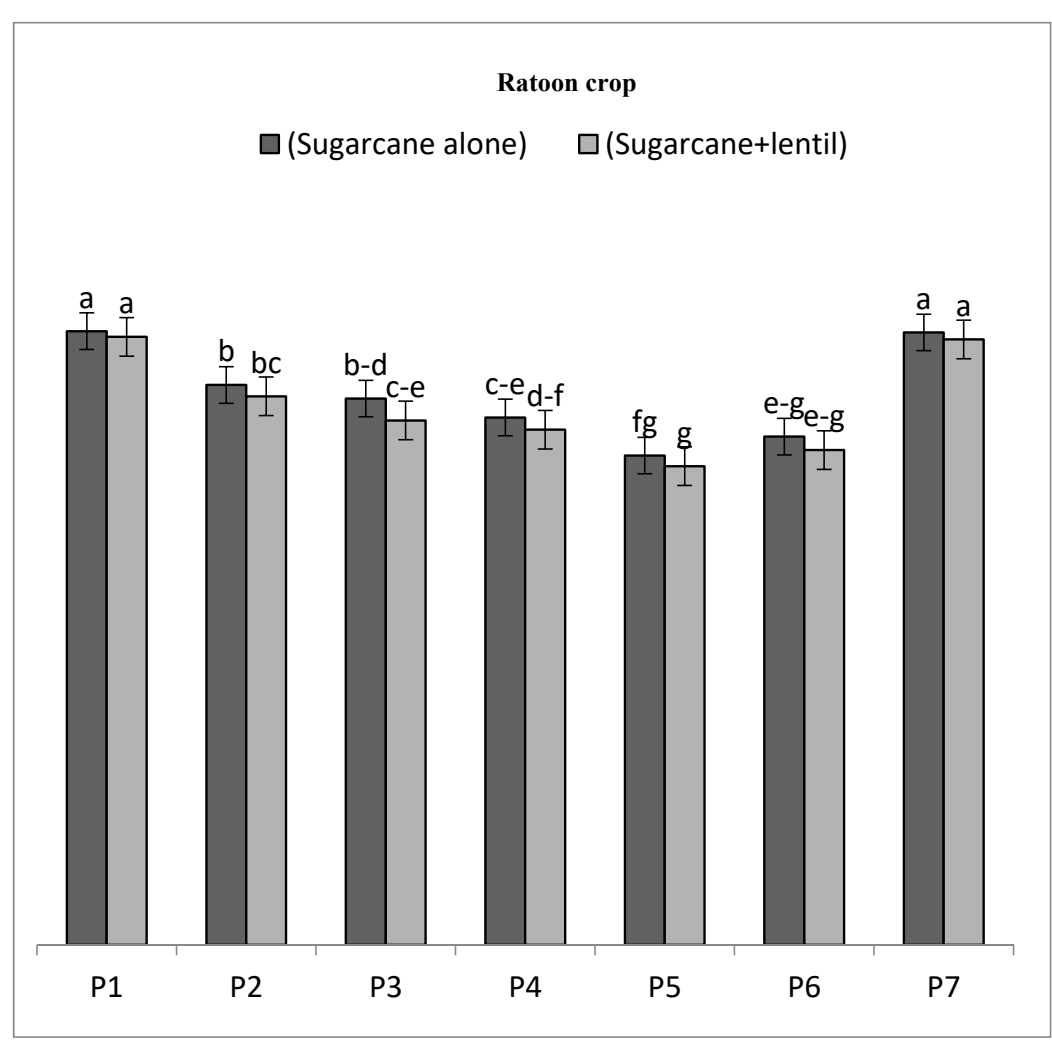

Figure 7. Total dry matter ( $\mathrm{t} / \mathrm{ha}$ ) of sugarcane as influenced by various planting patterns and lentil intercropping in (a) Plant crop and (b) ratoon crop. $\mathrm{P}_{1}$ : $45 \mathrm{~cm}$ pits with $90 \mathrm{~cm}$ diameter, $\mathrm{P}_{2}: 60 \mathrm{~cm}$ pits with $90 \mathrm{~cm}$ diameter, $\mathrm{P}_{3}: 75 \mathrm{~cm}$ pits with $90 \mathrm{~cm}$ diameter, $\mathrm{P}_{4}: 90 \mathrm{~cm}$ pits with $90 \mathrm{~cm}$ diameter, $\mathrm{P}_{5}: 60 \mathrm{~cm}$ single rows planting, $\mathrm{P}_{6}$ : $90 \mathrm{~cm}$ double rows planting, $\mathrm{P}_{7}$ : Trench planting at $120 \mathrm{~cm}$. Any two means not sharing a common letter(s) differ significantly at $5 \%$ probability. 


\subsection{Sugarcane Yield and Yield Components}

Results presented in Table 2; Table 3 reveals that various planting patterns significantly affected the parameters related to sugarcane yield and total sugar yield of sugarcane either grown alone or intercropped with lentil in both plant crop and ratoon crop. Among different planting patterns in plant cane, the number of millable canes in $45 \mathrm{~cm}$ pit planting was similar to $120 \mathrm{~cm}$ trench planting, but it was significantly greater than other planting patterns (Table 2). However, plant height was greater in $90 \mathrm{~cm}$ pit planting than other planting patterns except trench planting. Cane diameter was mostly similar in all planting patterns (Table 3). Stripped cane yield (SCY) and total sugar yield (TSY), with and without lentil intercropping, were significantly greater in $120 \mathrm{~cm}$ trench planting than all other planting patterns (Table 3). Similar results were seen in the ratoon crop with greater cane and sugar yields in $120 \mathrm{~cm}$ trench planting compared to other planting patterns. In comparison to all planting patterns, $90 \mathrm{~cm}$ apart single row planting remained at the bottom, as it gained the lowest values of all these parameters in both plant and ratoon crops. A similar trend of achieving higher plant height, cane diameter, cane length, stripped cane yield (SCY), and total sugar yield (TSY) was shown by the $120 \mathrm{~m}$ trench planting in ratoon crop. Compared to the traditional $60 \mathrm{~cm}$ apart single row planting pattern, $120 \mathrm{~cm}$ trench planting showed up to $4.34,12.12,8.63,43.18$, and $42.81 \%$ increase in plant height, cane diameter, cane length, SCY, and TSY, respectively.

\subsection{Lentil Yield}

Biological yields, seed yields, and harvest index's means of lentil intercropped with sugarcane under different planting patterns showed significant differences among themselves (Table 4). Lentil crop sown alone in $30 \mathrm{~cm}$ apart rows produced significantly higher biological and seed yields than other planting patterns in both 2013-2014 and 2014-2015 years. However, lentil intercrop performed better when sown along with $120 \mathrm{~cm}$ trench planted sugarcane, as it produced significantly higher biological and seed yields, which were $296 \%$ and $319 \%$ higher, respectively, than the lowest yields recorded with the lentil intercropped in $45 \mathrm{~cm}$ pit planting. Similarly, the harvest index (HI) of lentil was significantly greater in $120 \mathrm{~cm}$ trench planting compared to others, including the lentil sole planting method in 2013-2014. In 2014-2015, $120 \mathrm{~cm}$ trench planting had a similar HI as lentil alone, but both of them were significantly greater than other planting patterns. The comparison of land equivalent ratios (LER) calculated from different sugarcane-lentil intercropping geometries (Table 4) revealed that $120 \mathrm{~cm}$ trench planting with four rows of lentil intercrop attained significantly higher LER values (1.40 and 1.37 during cropping seasons 2013-2014 and 2014-2015, respectively) than all other planting patterns. 
Table 2. Yield contributing traits of sugarcane under different planting patterns with lentil intercropping.

\begin{tabular}{|c|c|c|c|c|c|c|}
\hline \multirow[b]{2}{*}{ Planting Methods (P) } & \multicolumn{2}{|c|}{ Number of Millable Canes $/ \mathrm{m}^{2}$} & \multicolumn{2}{|c|}{ Plant Height (cm) } & \multicolumn{2}{|c|}{ Cane Length $(\mathrm{cm})$} \\
\hline & $\begin{array}{c}\text { Sugarcane Alone } \\
\left(\mathrm{I}_{0}\right)\end{array}$ & $\begin{array}{l}\text { Sugarcane + Lentil } \\
\left(\mathrm{I}_{1}\right)\end{array}$ & $\begin{array}{c}\text { Sugarcane Alone } \\
\left(\mathrm{I}_{0}\right)\end{array}$ & $\begin{array}{l}\text { Sugarcane + Lentil } \\
\left(\mathrm{I}_{1}\right)\end{array}$ & $\begin{array}{c}\text { Sugarcane Alone } \\
\left(\mathrm{I}_{0}\right)\end{array}$ & $\begin{array}{c}\text { Sugarcane + Lentil } \\
\left(\mathrm{I}_{1}\right)\end{array}$ \\
\hline \multicolumn{7}{|c|}{ Plant crop } \\
\hline $\begin{array}{c}\mathrm{P}_{1}: 45 \mathrm{~cm} \text { pits with } 90 \mathrm{~cm} \\
\text { diameter }\end{array}$ & $19.00 \mathrm{a}$ & $17.50 \mathrm{ab}$ & 367.17 cde & $367.92 \mathrm{~b}-\mathrm{e}$ & $240.28 \mathrm{~b}-\mathrm{e}$ & $236.86 \mathrm{c}-\mathrm{f}$ \\
\hline $\begin{array}{c}\mathrm{P}_{2}: 60 \mathrm{~cm} \text { pits with } 90 \mathrm{~cm} \\
\text { diameter }\end{array}$ & $16.00 \mathrm{~b}-\mathrm{e}$ & $14.75 \mathrm{e}$ & $370.78 \mathrm{bcd}$ & $364.99 \mathrm{c}-\mathrm{f}$ & $243.67 \mathrm{bcd}$ & $237.62 b-f$ \\
\hline $\begin{array}{c}\mathrm{P}_{3}: 75 \mathrm{~cm} \text { pits with } 90 \mathrm{~cm} \\
\text { diameter }\end{array}$ & 15.25 cde & 14.25 ef & $369.16 \mathrm{bcd}$ & 366.28 cde & $246.45 \mathrm{bc}$ & $242.42 \mathrm{bcd}$ \\
\hline $\begin{array}{c}\mathrm{P}_{4}: 90 \mathrm{~cm} \text { pits with } 90 \mathrm{~cm} \\
\text { diameter }\end{array}$ & $15.00 \mathrm{de}$ & 13.75 efg & 381.11 a & $369.65 \mathrm{bcd}$ & 259.51 a & $250.60 \mathrm{ab}$ \\
\hline$P_{5}: 60 \mathrm{~cm}$ single row planting & $11.75 \mathrm{gh}$ & $11.25 \mathrm{~h}$ & $356.19 \mathrm{f}$ & 359.94 ef & $225.75 \mathrm{fg}$ & $222.00 \mathrm{~g}$ \\
\hline $\begin{array}{c}\mathrm{P}_{6}: 90 \mathrm{~cm} \text { double row } \\
\text { planting }\end{array}$ & $12.00 \mathrm{fgh}$ & $11.50 \mathrm{~h}$ & $364.49 \mathrm{def}$ & 361.74 def & $232.15 \mathrm{~d}-\mathrm{g}$ & $228.15 \mathrm{efg}$ \\
\hline $\mathrm{P}_{7}:$ Trench planting at $120 \mathrm{~cm}$ & $17.50 \mathrm{ab}$ & $17.00 \mathrm{a}-\mathrm{d}$ & $376.52 \mathrm{ab}$ & $374.44 \mathrm{abc}$ & $251.46 \mathrm{ab}$ & $247.26 \mathrm{abc}$ \\
\hline Mean & $15.21 \mathrm{~A}$ & $14.28 \mathrm{~B}$ & $370.10 \mathrm{~A}$ & $365.67 \mathrm{~B}$ & $242.75 \mathrm{~A}$ & $287.84 \mathrm{~B}$ \\
\hline \multicolumn{7}{|c|}{ Ratoon crop } \\
\hline $\begin{array}{c}\mathrm{P}_{1}: 45 \mathrm{~cm} \text { pits with } 90 \mathrm{~cm} \\
\text { diameter }\end{array}$ & $15.75 \mathrm{a}$ & $14.50 \mathrm{ab}$ & $322.39 \mathrm{~b}-\mathrm{e}$ & $320.64 \mathrm{~b}-\mathrm{e}$ & 216.31 a-e & 208.55 def \\
\hline $\begin{array}{c}\mathrm{P}_{2}: 60 \mathrm{~cm} \text { pits with } 90 \mathrm{~cm} \\
\text { diameter }\end{array}$ & $13.00 \mathrm{~b}-\mathrm{e}$ & $12.00 \mathrm{c}-\mathrm{g}$ & $324.34 \mathrm{a}-\mathrm{d}$ & $321.84 \mathrm{~b}-\mathrm{e}$ & $217.37 \mathrm{a}-\mathrm{d}$ & $209.37 \mathrm{c}-\mathrm{f}$ \\
\hline $\begin{array}{c}\mathrm{P}_{3}: 75 \mathrm{~cm} \text { pits with } 90 \mathrm{~cm} \\
\text { diameter }\end{array}$ & $12.75 \mathrm{~b}-\mathrm{f}$ & $11.50 \mathrm{~d}-\mathrm{i}$ & $325.88 \mathrm{abc}$ & $322.63 \mathrm{~b}-\mathrm{e}$ & $219.67 \mathrm{abc}$ & $214.17 \mathrm{~b}-\mathrm{e}$ \\
\hline $\begin{array}{c}\mathrm{P}_{4}: 90 \mathrm{~cm} \text { pits with } 90 \mathrm{~cm} \\
\text { diameter }\end{array}$ & $12.50 \mathrm{c}-\mathrm{g}$ & $11.00 \mathrm{f}-\mathrm{i}$ & $326.10 \mathrm{ab}$ & 323.02 a-e & $225.76 \mathrm{a}$ & $222.69 \mathrm{ab}$ \\
\hline$P_{5}: 60 \mathrm{~cm}$ single row planting & 10.50 ghi & $9.75 \mathrm{~h}$ & 318.44 de & $316.44 \mathrm{e}$ & $202.00 \mathrm{f}$ & $200.50 \mathrm{f}$ \\
\hline $\begin{array}{c}\mathrm{P}_{6}: 90 \mathrm{~cm} \text { double row } \\
\text { planting }\end{array}$ & $11.00 \mathrm{e}-\mathrm{i}$ & $10.25 \mathrm{hi}$ & $320.49 \mathrm{~b}-\mathrm{e}$ & 318.74 cde & 207.07 ef & 205.90 ef \\
\hline $\mathrm{P}_{7}:$ Trench planting at $120 \mathrm{~cm}$ & $13.50 \mathrm{bc}$ & $13.50 \mathrm{bcd}$ & $330.20 \mathrm{a}$ & $323.41 \mathrm{a}-\mathrm{e}$ & $224.80 \mathrm{a}$ & $221.51 \mathrm{ab}$ \\
\hline Mean & $12.75 \mathrm{~A}$ & $11.78 \mathrm{~B}$ & $323.98 \mathrm{~A}$ & $320.96 \mathrm{~B}$ & $216.14 \mathrm{~A}$ & $211.81 \mathrm{~B}$ \\
\hline
\end{tabular}

Any two means in a column not sharing a common letter(s) differ significantly at $5 \%$ probability. 
Table 3. Yield and quality of sugarcane under different planting patterns with lentil intercropping.

\begin{tabular}{|c|c|c|c|c|c|c|}
\hline \multirow[b]{2}{*}{ Planting Methods (P) } & \multicolumn{2}{|c|}{ Cane Diameter $(\mathrm{cm})$} & \multicolumn{2}{|c|}{ Stripped Cane Yield (t/ha) } & \multicolumn{2}{|c|}{ Total Sugar Yield (t/ha) } \\
\hline & $\begin{array}{c}\text { Sugarcane Alone } \\
\left(\mathrm{I}_{0}\right)\end{array}$ & $\begin{array}{c}\text { Sugarcane + Lentil } \\
\left(\mathrm{I}_{1}\right)\end{array}$ & $\begin{array}{c}\text { Sugarcane Alone } \\
\left(\mathrm{I}_{0}\right)\end{array}$ & $\begin{array}{c}\text { Sugarcane + Lentil } \\
\left(\mathrm{I}_{1}\right)\end{array}$ & $\begin{array}{c}\text { Sugarcane Alone } \\
\left(\mathrm{I}_{0}\right)\end{array}$ & $\begin{array}{c}\text { Sugarcane + Lentil } \\
\left(\mathrm{I}_{1}\right)\end{array}$ \\
\hline \multicolumn{7}{|c|}{ Plant crop } \\
\hline $\begin{array}{c}\mathrm{P}_{1}: 45 \mathrm{~cm} \text { pits with } 90 \mathrm{~cm} \\
\text { diameter }\end{array}$ & $2.40 \mathrm{ab}$ & $2.36 \mathrm{ab}$ & $142.88 \mathrm{~b}$ & $140.50 \mathrm{bc}$ & $19.11 \mathrm{~b}$ & $18.83 \mathrm{bc}$ \\
\hline $\begin{array}{c}\mathrm{P}_{2}: 60 \mathrm{~cm} \text { pits with } 90 \mathrm{~cm} \\
\text { diameter }\end{array}$ & $2.44 \mathrm{ab}$ & $2.39 \mathrm{ab}$ & $137.00 \mathrm{bc}$ & $136.61 \mathrm{c}$ & $18.44 \mathrm{c}$ & $18.27 \mathrm{c}$ \\
\hline $\begin{array}{c}\mathrm{P}_{3}: 75 \mathrm{~cm} \text { pits with } 90 \mathrm{~cm} \\
\text { diameter }\end{array}$ & $2.45 \mathrm{ab}$ & $2.41 \mathrm{ab}$ & $124.49 \mathrm{~d}$ & $123.03 \mathrm{~d}$ & $17.64 \mathrm{~d}$ & $16.28 \mathrm{e}$ \\
\hline $\begin{array}{c}\mathrm{P}_{4}: 90 \mathrm{~cm} \text { pits with } 90 \mathrm{~cm} \\
\text { diameter }\end{array}$ & $2.51 \mathrm{ab}$ & $2.49 \mathrm{ab}$ & $115.97 \mathrm{e}$ & $115.50 \mathrm{e}$ & $15.64 \mathrm{f}$ & $15.35 \mathrm{f}$ \\
\hline $\begin{array}{c}\mathrm{P}_{5}: 60 \mathrm{~cm} \text { single rows } \\
\text { planting }\end{array}$ & $2.32 \mathrm{ab}$ & $2.28 \mathrm{~b}$ & $99.49 \mathrm{~g}$ & $95.32 \mathrm{~g}$ & $13.40 \mathrm{~h}$ & $12.70 \mathrm{i}$ \\
\hline $\begin{array}{c}\mathrm{P}_{6}: 90 \mathrm{~cm} \text { double rows } \\
\text { planting }\end{array}$ & $2.37 \mathrm{ab}$ & $2.34 \mathrm{ab}$ & $108.45 \mathrm{f}$ & $98.05 \mathrm{~g}$ & $14.54 \mathrm{~g}$ & $13.19 \mathrm{hi}$ \\
\hline $\mathrm{P}_{7}:$ Trench planting at $120 \mathrm{~cm}$ & $2.54 \mathrm{a}$ & $2.52 \mathrm{a}$ & 154.36 a & $153.10 \mathrm{a}$ & $20.62 \mathrm{a}$ & $20.50 \mathrm{a}$ \\
\hline Mean & 2.43 & 2.39 & $126.09 \mathrm{~A}$ & $123.09 \mathrm{~B}$ & $17.06 \mathrm{~A}$ & $16.44 \mathrm{~B}$ \\
\hline \multicolumn{7}{|c|}{ Ratoon crop } \\
\hline $\begin{array}{c}\mathrm{P}_{1}: 45 \mathrm{~cm} \text { pits with } 90 \mathrm{~cm} \\
\text { diameter }\end{array}$ & $2.29 \mathrm{a}-\mathrm{e}$ & $2.23 \mathrm{de}$ & $122.03 \mathrm{~b}$ & $121.85 \mathrm{~b}$ & $16.89 \mathrm{~b}$ & $16.84 \mathrm{~b}$ \\
\hline $\begin{array}{c}\mathrm{P}_{2}: 60 \mathrm{~cm} \text { pits with } 90 \mathrm{~cm} \\
\text { diameter }\end{array}$ & $2.32 \mathrm{a}-\mathrm{d}$ & 2.24 cde & $116.28 \mathrm{c}$ & $115.98 \mathrm{~cd}$ & $16.02 \mathrm{c}$ & $16.00 \mathrm{c}$ \\
\hline $\begin{array}{c}\mathrm{P}_{3}: 75 \mathrm{~cm} \text { pits with } 90 \mathrm{~cm} \\
\text { diameter }\end{array}$ & $2.33 \mathrm{abc}$ & $2.25 \mathrm{~b}-\mathrm{e}$ & 111.73 de & 110.78 ef & $15.24 \mathrm{de}$ & $15.28 \mathrm{~d}$ \\
\hline $\begin{array}{c}\mathrm{P}_{4}: 90 \mathrm{~cm} \text { pits with } 90 \mathrm{~cm} \\
\text { diameter }\end{array}$ & $2.35 \mathrm{ab}$ & $2.27 \mathrm{~b}-\mathrm{e}$ & 107.84 ef & $106.84 \mathrm{f}$ & $14.79 \mathrm{f}$ & 14.80 ef \\
\hline$P_{5}: 60 \mathrm{~cm}$ single row planting & $2.26 \mathrm{~b}-\mathrm{e}$ & $2.20 \mathrm{e}$ & $92.84 \mathrm{~h}$ & $90.99 \mathrm{~h}$ & $12.65 \mathrm{~h}$ & $12.52 \mathrm{~h}$ \\
\hline $\begin{array}{c}\mathrm{P}_{6}: 90 \mathrm{~cm} \text { double row } \\
\text { planting }\end{array}$ & $2.28 \mathrm{~b}-\mathrm{e}$ & $2.21 \mathrm{e}$ & $101.28 \mathrm{~g}$ & $100.98 \mathrm{~g}$ & $13.88 \mathrm{~g}$ & $14.07 \mathrm{~g}$ \\
\hline $\mathrm{P}_{7}:$ Trench planting at $120 \mathrm{~cm}$ & $2.39 \mathrm{a}(8.63)$ & $2.29 \mathrm{a}-\mathrm{e}$ & $130.28 \mathrm{a}$ & $130.10 \mathrm{a}$ & $17.88 \mathrm{a}$ & $17.86 \mathrm{a}$ \\
\hline Mean & $2.31 \mathrm{~A}$ & $2.24 \mathrm{~B}$ & 111.75 & 111.07 & $15.30 \mathrm{~A}$ & $14.36 \mathrm{~B}$ \\
\hline
\end{tabular}

Any two means in a column not sharing a common letter(s) differ significantly at $5 \%$ probability. 
Table 4. Yields, harvest index of lentil, and land equivalent ratio under different planting patterns with lentil intercropping.

\begin{tabular}{|c|c|c|c|c|c|c|c|c|}
\hline \multirow{2}{*}{ Planting Methods (P) } & \multicolumn{2}{|c|}{ Biological Yield (kg/ha) } & \multicolumn{2}{|c|}{ Seed Yield (kg/ha) } & \multicolumn{2}{|c|}{ Harvest Index (HI) } & \multicolumn{2}{|c|}{ Land Equivalent Ratio } \\
\hline & 2013-2014 & 2014-2015 & 2013-2014 & 2014-2015 & 2013-2014 & 2014-2015 & 2013-2014 & 2014-2015 \\
\hline $\mathrm{P}_{1}: 45 \mathrm{~cm}$ pits with $90 \mathrm{~cm}$ diameter + one row of lentil & $517.50 \mathrm{e}$ & $587.50 \mathrm{e}$ & $150.30 \mathrm{f}$ & $165.30 \mathrm{e}$ & $29.03 \mathrm{ab}$ & $28.08 \mathrm{~b}$ & $1.09 \mathrm{~d}$ & $1.10 \mathrm{~d}$ \\
\hline $\mathrm{P}_{2}: 60 \mathrm{~cm}$ pits with $90 \mathrm{~cm}$ diameter + two rows of lentil & $1022.50 \mathrm{~d}$ & $1102.50 \mathrm{~d}$ & 265.30 de & $275.00 \mathrm{~d}$ & $25.94 \mathrm{c}$ & $24.93 c$ & $1.18 \mathrm{c}$ & $1.16 \mathrm{c}$ \\
\hline $\mathrm{P}_{3}: 75 \mathrm{~cm}$ pits with $90 \mathrm{~cm}$ diameter + two rows of lentil & $1032.00 \mathrm{~d}$ & $1117.50 \mathrm{~d}$ & $275.00 \mathrm{~d}$ & $285.00 \mathrm{~d}$ & $26.66 \mathrm{c}$ & $25.49 \mathrm{c}$ & $1.18 \mathrm{c}$ & $1.16 \mathrm{c}$ \\
\hline $\mathrm{P}_{4}: 90 \mathrm{~cm}$ pits with $90 \mathrm{~cm}$ diameter + three rows of lentil & $1510.00 \mathrm{c}$ & $1570.50 \mathrm{c}$ & $394.50 \mathrm{c}$ & $402.00 \mathrm{c}$ & $26.13 c$ & $25.60 \mathrm{c}$ & $1.26 \mathrm{~b}$ & $1.23 \mathrm{~b}$ \\
\hline $\mathrm{P}_{5}: 60 \mathrm{~cm}$ single row planting + one row of lentil & $530.00 \mathrm{e}$ & $595.00 \mathrm{e}$ & $129.80 \mathrm{f}$ & $145.00 \mathrm{e}$ & $26.48 \mathrm{c}$ & $24.37 \mathrm{c}$ & $1.05 \mathrm{~d}$ & $1.07 \mathrm{~d}$ \\
\hline $\mathrm{P}_{6}: 90 \mathrm{~cm}$ double row planting + two rows of lentil & $1027.50 \mathrm{~d}$ & $1080.00 \mathrm{~d}$ & $240.30 \mathrm{e}$ & $265.30 \mathrm{~d}$ & $23.37 \mathrm{~d}$ & $24.53 \mathrm{c}$ & $1.07 \mathrm{~d}$ & $1.15 \mathrm{c}$ \\
\hline $\mathrm{P}_{7}$ : Trench planting at $120 \mathrm{~cm}+$ four rows of lentil & $1987.00 \mathrm{~b}$ & $2052.50 \mathrm{~b}$ & $598.00 \mathrm{~b}$ & $629.80 \mathrm{~b}$ & $29.96 \mathrm{a}$ & $30.68 \mathrm{a}$ & $1.40 \mathrm{a}$ & $1.37 \mathrm{a}$ \\
\hline $\mathrm{P}_{8}$ : Lentil alone $30 \mathrm{~cm}$ spaced single rows (twelve rows) & $5215.00 \mathrm{a}$ & 5390.00 a & $1476.00 \mathrm{a}$ & $1700.00 \mathrm{a}$ & $28.30 \mathrm{~b}$ & $31.54 \mathrm{a}$ & - & - \\
\hline LSD & 45.20 & 61.25 & 27.40 & 29.87 & 1.54 & 1.28 & 0.049 & 0.054 \\
\hline
\end{tabular}

Any two means in a column not sharing common letter(s) differ significantly at $5 \%$ probability. 


\subsection{Economic Analysis}

Possibly, productivity as well as adoptability of an intercropping system are ultimately determined by their net monetary gain. Based on average net field benefits from both plant and ratoon crop, the highest NFB of Rs. 491703/ha was found in $120 \mathrm{~cm}$ trench planting + lentil intercropping, whereas the minimum NFB of Rs. 302559/ha was recorded in $60 \mathrm{~cm}$ single rows planting + lentil. Overall, higher net field benefits were obtained when lentil was intercropped in sugarcane. The better result of the $120 \mathrm{~cm}$ trench with lentil intercropping might be due to more lentil plant population when sown in between the empty spaces as compared to pit planting: $60 \mathrm{~cm}$ single row planting or $90 \mathrm{~cm}$ double row planting. Average data on net return of both plant and ratoon crops of sugarcane are presented in Table 5. Maximum net return of Rs. 321254/ha was recorded in $120 \mathrm{~cm}$ trench planting with lentil as an intercrop; however, the minimum net return of Rs. 132110/ha was noted in $60 \mathrm{~cm}$ single rows planting + lentil.

The results of BCR are presented in Table 5. Average data on BCR of both plant and ratoon crops of sugarcane are presented in Table 5. Maximum BCR (2.01) was recorded in $120 \mathrm{~cm}$ trench planting with lentil as an intercrop; however, the least BCR (1.50) was noted in $60 \mathrm{~cm}$ apart single row planting + lentil. Overall, the maximum BCR values were examined in all treatments of ratoon crop, because no sowing and tillage operations were carried out that ultimately resulted in a reduction of the overall cost of production.

Since the net field benefits are not the final criteria for recommendation to the farmers, the marginal analysis was done to conclude the most profitable sugarcane intercropping system. The dominance analysis is given in Table 5. Based on two-year average data, sugarcane planting methods $\left(\mathrm{P}_{12}, \mathrm{P}_{13}\right.$, $\mathrm{P}_{3}, \mathrm{P}_{10}, \mathrm{P}_{2}, \mathrm{P}_{9}, \mathrm{P}_{1}$, and $\left.\mathrm{P}_{8}\right)$ underwent dominance analysis. Those treatments that were signed as " $\mathrm{D}$ " in the dominance analysis were not selected for marginal analysis. The results of sugarcane-lentil intercropping systems have been described in Table 5. Based on an average MRR, the maximum $(16,902 \%)$ value was obtained from $120 \mathrm{~cm}$ trench planting. 
Table 5. Effect of different sugarcane-lentil based intercropping systems on average net return, average net field benefits, and average benefit-cost ratio 2013-2016 (each value is the average total experimental duration). MRR: marginal rate of return.

\begin{tabular}{|c|c|c|c|c|c|c|c|c|c|c|c|}
\hline Planting Methods (P) & $\begin{array}{l}\text { Variable Cost } \\
\left.\text { (Rs. ha } \text { he }^{-1}\right)\end{array}$ & $\begin{array}{l}\text { Total Cost } \\
\text { (Rs. ha-1) }\end{array}$ & $\begin{array}{c}\text { Gross } \\
\text { Income } \\
\left.\text { (Rs. ha }^{-1}\right)\end{array}$ & $\begin{array}{l}\text { Net Return } \\
\left(\text { Rs. ha }{ }^{-1}\right)\end{array}$ & $\begin{array}{c}\text { Net Field } \\
\text { Benefit } \\
\text { (Rs. ha-1) }\end{array}$ & $\begin{array}{c}\text { Benefit } \\
\text { Cost Ratio }\end{array}$ & $\begin{array}{l}\text { Cost That } \\
\text { Vary (Rs.) }\end{array}$ & $\begin{array}{c}\text { Net Field } \\
\text { Benefits } \\
\text { (Rs.) }\end{array}$ & $\begin{array}{c}\text { Marginal } \\
\text { Cost } \\
\text { (Rs.) }\end{array}$ & $\begin{array}{c}\text { Marginal } \\
\text { Net Profit } \\
\text { (Rs.) }\end{array}$ & MRR (\%) \\
\hline $\mathrm{P}_{1}: 45 \mathrm{~cm}$ pits with $90 \mathrm{~cm}$ diameter & 152,705 & 323,154 & 553,993 & 230,839 & 401,288 & 1.71 & 92,245 & 310,269 & - & - & - \\
\hline$P_{2}: 60 \mathrm{~cm}$ pits with $90 \mathrm{~cm}$ diameter & 142,147 & 312,596 & 529,658 & 217,061 & 387,510 & 1.69 & 94,379 & D & 2133 & -7710 & D \\
\hline $\mathrm{P}_{3}: 75 \mathrm{~cm}$ pits with $90 \mathrm{~cm}$ diameter & 131,754 & 302,203 & 494,202 & 191,999 & 362,448 & 1.64 & 99,068 & 339,825 & 4689 & 37,266 & 795 \\
\hline $\mathrm{P}_{4}: 90 \mathrm{~cm}$ pits with $90 \mathrm{~cm}$ diameter & 116,822 & 287,271 & 468,359 & 181,087 & 351,536 & 1.63 & 103,194 & D & 4126 & -9257 & D \\
\hline$P_{5}: 60 \mathrm{~cm}$ single row planting & 92,245 & 262,694 & 402,514 & 139,820 & 310,269 & 1.53 & 116,822 & 351,536 & 13,628 & 20,969 & 154 \\
\hline $\mathrm{P}_{6}: 90 \mathrm{~cm}$ double row planting & 99,068 & 269,517 & 438,893 & 169,376 & 339,825 & 1.63 & 129,127 & 365,253 & 12,305 & 13,716 & 111 \\
\hline$P_{7}$ : Trench planting at $120 \mathrm{~cm}$ & 129,720 & 300,169 & 595,207 & 295,038 & 465,487 & 1.98 & 129,720 & 465,487 & 593 & 100,234 & 16,902 \\
\hline $\mathrm{P}_{8}: 45 \mathrm{~cm}$ pits with $90 \mathrm{~cm}$ diameter + lentil & 156,801 & 327,250 & 555,604 & 228,354 & 398,803 & 1.70 & 131,754 & D & 2034 & $-103,039$ & D \\
\hline$P_{9}: 60 \mathrm{~cm}$ pits with $90 \mathrm{~cm}$ diameter + lentil & 150,725 & 321,174 & 545,894 & 224,720 & 395,169 & 1.70 & 139,953 & D & 8199 & 5684 & D \\
\hline$P_{10}: 75 \mathrm{~cm}$ pits with $90 \mathrm{~cm}$ diameter + lentil & 139,953 & 310,402 & 508,085 & 197,683 & 368,132 & 1.64 & 142,147 & D & 2194 & 19,378 & D \\
\hline$P_{11}: 90 \mathrm{~cm}$ pits with $90 \mathrm{~cm}$ diameter + lentil & 129,127 & 299,576 & 494,380 & 194,804 & 365,253 & 1.65 & 149,077 & 491,703 & 6930 & 104,193 & 1504 \\
\hline $\mathrm{P}_{12}: 60 \mathrm{~cm}$ single row planting + lentil & 94,379 & 264,828 & 396,937 & 132,110 & 302,559 & 1.50 & 150,725 & D & 1648 & $-96,534$ & D \\
\hline $\mathrm{P}_{13}: 90 \mathrm{~cm}$ double row planting + lentil & 103,194 & 273,643 & 433,762 & 160,119 & 330,568 & 1.59 & 152,705 & D & 1981 & 6119 & D \\
\hline $\mathrm{P}_{14}:$ Trench planting at $120 \mathrm{~cm}+$ lentil & 149,077 & 319,526 & 640,780 & 321,254 & 491,703 & 2.01 & 156,801 & D & 4096 & -2485 & D \\
\hline
\end{tabular}

Letter ' $\mathrm{D}$ ' represent dominant treatments. 


\section{Discussion}

Intercropping of a legume crop in sugarcane is advantageous as it improves the growth and yield of both crops by enhancing the soil nutrient contents and benefits the microbial population [30]. However, the choice of suitable sugarcane planting pattern for adjusting intercrop to draw maximum economic benefit is important [31]. The present study showed significant variation in growth, sugarcane yield parameters, and total sugar yield attributes of sugarcane sown along with lentil intercrop. Variability in LAI of sugarcane in different planting patterns was ascribed to variable plant population and availability of moisture, nutrients, optimal temperature, and aeration. The greater LAI of sugarcane sown in $120 \mathrm{~cm}$ trench planting/45 cm pit planting compared to other methods could be due to more plant population and better leaf development. These findings are in agreement with those of [32], who reported significant changes in LAI due to intercropping in sugarcane. The difference in LAD among various planting patterns was due to the variation in LAI achieved as a result of utilization of resources in different planting patterns; in some papers $[33,34]$, it was also noted that different planting patterns had significant effects on LAD of sugarcane crop.

Significantly higher CGR in sole sugarcane (SC) might be due to less competition for free environment, and more availability of nutrients and space that ultimately led to a well-developed root system. A deep root system provides nutrient and moisture availability for plants. The above conclusions are matched with the those of [35], who reported more CGR of sole sugarcane planted at triple row strips than intercrops. The variation in NAR under different treatments might be ascribed to variation in LAI (Figure 6), LAD (Figure 4), production of total dry matter (Figure 7), and CGR (Figure 5). Variability in the production of total dry matter of sugarcane in different planting patterns was ascribed to variability in plant population, intercrop competition, and availability of different farm resources.

Variability in millable canes $/ \mathrm{m}^{2}$ was possibly due to appreciative effect of increased nutrient accessibility, better air circulation and interception of light that resulted in reduced shoot mortality and better growth of cane due to better utilization of farm inputs. An increase in millable canes $/ \mathrm{m}^{2}$ for sole sugarcane could be possibly due to a higher number of tillers $/ \mathrm{m}^{2}$. Similar results confirmed by [36-38], who reported a significant destructive effect of linseed, mustard, alfalfa, and sunflower on millable canes $/ \mathrm{m}^{2}$. These results are also in line with those of [39]. The variation in plant height under different treatments might be due to variation in utilization of farm resources by crop plants. Moreover, better penetration of sunlight to the crop plant might improve the availability of photosynthates to cane sown in trench planting at $120 \mathrm{~cm}$ and $90 \mathrm{~cm}$ pits that promoted growth, resulting in increased values of plant height. These results are in line with those of [40], who reported that sugarcane planted in paired rows accommodating two rows of grain Amaranth sp., as an intercrop produced plants of maximum height. These results were also confirmed by [41], who noted an increased plant height in trench planting at $120 \mathrm{~cm}$ as compared to $60 \mathrm{~cm}$ single rows. Additionally, the authors of [42] documented more height of sugarcane plants in $0.5 \mathrm{~m}$-spaced rows compared to $1.5 \mathrm{~m}$-spaced rows. The maximum reduction in cane length was noted when sugarcane was intercropped with lentil both in plants as well as in ratoon crop. The dissimilarity in cane length under different treatments might be due to a higher number of internodes per cane when sugarcane was planted as sole crop compared to sugarcane + lentil. The authors in [43] reported that intercropping in sugarcane significantly affected cane length.

Variability in cane diameter in pit and trench planting with $60 \mathrm{~cm}$ single row and $90 \mathrm{~cm}$ double row strips of sole sugarcane and sugarcane with lentil may be attributed to better cane growth in pits and trench planting because of adequate supply of various agricultural inputs, such as water, fertilizer, etc., which were applied directly to the pits and within the trench instead of mixing them with the surface soil over the entire plant area. These outcomes are in close conformity with the conclusions of [44], who determined that cane diameter was increased as a result of increasing row spacing, while [45] stated that the diameter of cane was not influenced through different sowing geometry. Significantly more SCY from trench planting in sugarcane treatments over other treatments 
was possibly due to maximum LAI (Figure 3), CGR (Figure 5), TDM (Figure 7), and NAR (Figure 6). The more cane yield of the SC might be due to less competition for resources that enhanced the cane potential during developmental stage. The above findings are in line with [46], who observed a $21.8 \%$ reduction in yield of sugarcane when it was intercropped with sarsoon (Brassica compestris). Likewise, a better yield of sugarcane was obtained when planted as a sole crop compared to the intercropped method [47]. The above results are also supported by [48], who observed that different intercrops except Sesbania reduced the yield of cane significantly. Higher values of total sugar yield by $120 \mathrm{~cm}$ trench planting might be due to higher SCY (Table 2). These results supported by [39,49], who noted that sugarcane sown at 120 spaced trenches and $90 \mathrm{~cm}$ double rows produced significantly more sugar yield (total sucrose) than that sown at $60 \mathrm{~cm}$-spaced single rows. Similarly, [50] hypothesized that wider spaced rows gave more sugar yield than narrow spaced rows.

The results of the present study indicated that biological and seed yields as well as HI of lentil inter-crop were also varied significantly under different planting patterns of sugarcane. The variability in biological yield of lentil in intercropping treatments might be due to variable plant density. Diminution in the biological yield of lentil in intercropped treatments might be due to competition for light, water, nutrients, etc. between the sugarcane and lentil, while the increased biological yield in lentil alone can be attributed to competition free environment. These results are in conformity to those of [51], who found increased biological yield when mung bean (vigna radiate) was sown alone in an intercropping study. Less grain yield in the intercropping system is possibly due to low plant density establishment, seed per pods (data not shown), and 1000-grain weight in comparison with sole lentil. These results are supported by [52], who observed that lentil yield was reduced to a greater degree by the intercropping systems. The reduction in HI of lentil occurred due to its intercropping with sugarcane planted in $60 \mathrm{~cm}$ single row planting and $90 \mathrm{~cm}$ double row planting as well as 60 and $75 \mathrm{~cm}$ pits of $90 \mathrm{~cm}$ diameter. The reduction in $\mathrm{HI}$ of lentil with these intercropping patterns might be attributed to its reduced reproductive growth at the expense of higher vegetative growth. These findings are in line with those of [53], who observed the reduction in harvest index of lentil crop when it was intercropped in linseed (Linum usitatissimum), methra (Trigonella foenum-graecum), and wheat (Triticum aestivum). Regarding LER, the significantly highest land equivalent ratio was achieved in $120 \mathrm{~cm}$ trench planted sugarcane intercropping systems, likely due to better utilization of inputs. Sugarcane planted in $120 \mathrm{~cm}$ trench planting showed the highest LER due to the increased lentil plant population. The benefits of intercropping of sugarcane with lentil were also reported by [54], who found LERs of 1.43 and 1.38 during the two years of study.

In conclusion, $120 \mathrm{~cm}$ trench planting pattern of sugarcane along with lentil intercropping outperformed in improving the LER and gave maximum economic return as compared to other intercropping patterns and sole planting of sugarcane.

Author Contributions: M.N.: methodology, writing the original draft preparation, and collecting experimental data. A.T.: supervision. H.S.: Investigations and improving the first draft. S.J.: reviewing and editing the manuscript. M.E.S., M.S., and M.I.: reviewed the manuscript. M.A.S. and U.A.: data analysis. All authors have read and agreed to the published version of the manuscript.

Conflicts of Interest: The authors declare no conflict of interest.

\section{References}

1. GOP. Economic Survey of Pakistan 2017-2018; Ministry of Food Agriculture and Livestock, Federal Bureau of Statistics: Islamabad, Pakistan, 2018.

2. FAO. Statistical Database. Food and Agriculture Organization (FAO). 2012. Available online: www.faostat. fao.org (accessed on 15 December 2019).

3. Majid, A. Sugarcane variety composition in Pakistan. Pak. Sugar J. 2007, 22, 2-21.

4. Nazir, A.; Jariko, G.A.; Junejo, M.A. Factors affecting sugarcane production in Pakistan. Pak. J. Commer. Soc. Sci. 2013, 7, 89-95. 
5. Bashir, S.; Saeed, M. Biomass production and partitioning in sugarcane genotype SPSG 394 as influenced by planting pattern and seeding density. J. Agric. Res. 2000, 36, 129-137.

6. Mahmood, A.; Ishfaq, M.; Iqbal, J.; Nazir, M.S. Agronomic performance and juice quality of autumn planted sugarcane (Saccharum officinarum L.) as affected by flat, ditch and pit planting under different spatial arrangements. Int. J. Agric. Biol. 2007, 9, 167-169.

7. Ehsanullah; Jabran, K.; Jamil, M.; Ghaffar, A. Optimizing the sugarcane row spacing and seeding density to improve its yield and quality. Crop Environ. 2011, 2, 1-5.

8. Maqsood, M.; Iqbal, M.; Tayyab, M. Comparative productivity performance of sugarcane (Saccharum officinarum L.) sown in different planting patterns at farmer's field. Pak. J. Agric. Sci. 2005, 42, 25-28.

9. Zafar, M.; Tanveer, A.; Cheema, Z.A.; Ashraf, M. Weed-crop competition effects on growth and yield of sugarcane planted using two methods. Pak. J. Bot. 2010, 42, 815-823.

10. Ghaffar, A.; Ehsanullah, N.A.; Khan, S.H. Influence of zinc and iron on yield and quality of sugarcane planted under various trench spacing. Pak J. Agric. Sci. 2011, 48, 25-33.

11. Singh, N.; Jain, J.L.; Singh, D.K. Impact of planting techniques on sugarcane and sugar productivity at Harinagar, Bihar. Indian Sugar Technol. 2009, 59, 19-22.

12. Sureka, B.K.; Shahi, V.P.; Singh, I.S.; Singh, N. Ring pit planting technique of sugarcane adopted to increase cane productivity at Bharat sugar mills, Sidhwalia, Gopalganj Bihar. Indian Sugar 2009, 59, 69-74.

13. Chand, M.; Khippal, A.; Singh, S.; Lal, R.; Singh, R. Effect of planting material and seed rate in pit planted sugarcane (Saccharum spp. hybrid complex) in sub-tropical India. Indian J. Agron. 2011, 56, 78-82.

14. Chattha, M.U.; Ehsanullah. Agro-quantitative and qualitative performance of different cultivars and strains of sugarcane (Saccharum officinarum L.). Pak. Sugar J. 2003, 18, 2-5.

15. Akhtar, M.; Ashraf, M.; Akhtar, M.E. Sugarcane yield gap analysis: Future options for Pakistan. Sci. Technol. Dev. 2003, 1, 38-48.

16. Yadav, R.L. Sugarcane Production Technology; Constraints and Potentialities; Oxford and IBH Publishing Co. (Pvt.) Ltd.: Bombay, India, 1991; p. 204.

17. Rehman, A.; Ehsanullah. Increasing Yield of Ratoon Sugarcane. 2008. Available online: http://www.dawn. com/news/296976/increasing-yield-of-ratoon-sugarcane (accessed on 22 December 2019).

18. Malik, K.B.; Ali, F.G.; Khaliq, A. Effect of plant population and row spacing on cane yield of spring-planted cane. J. Agric. Res. 1996, 34, 389-395.

19. Eskandari, H.; Ghanbari, A. Environmental resource consumption in wheat and bean intercropping: Comparison of nutrient uptake and light interception. Not. Sci. Biol. 2010, 2, 100-103. [CrossRef]

20. Imran, M.; Ali, A.; Waseem, M.; Tahir, M.; Mohsin, A.U.; Shehzad, M.; Ghaffari, A.; Rehman, H. Bio-economic assessment of sunflower mungbean intercropping system at different planting geometry. Int. Res. J. Agric. Sci. 2011, 1, 126-136.

21. Alizadeh, K.; Silva, J.A.T. Mix cropping of annual feed legumes with barley improves feed quantity and crude protein content under dry land conditions in Iran. Maejo Int. J. Sci. Technol. 2013, 7, 42-47.

22. Akhtar, M.; Yaqub, M.; Iqbal, Z.; Ashraf, M.Y.; Akhter, J.; Hussain, F. Improvement in yield and nutrient uptake by co-cropping of wheat and chickpea. Pak. J. Bot. 2010, 42, 4043-4049.

23. Pawar, M.W.; More, D.B.; Amodkar, V.T.; Joshi, S. Effect of inter-settling spacing on sugarcane yield and quality. Sugar Technol. 2005, 7, 87-89. [CrossRef]

24. Rana, N.S.; Kumar, S.; Saini, S.K.; Panwar, G.S. Production potential of autumn sugarcane-based intercropping systems as influenced by intercrops and row spacing. Indian J. Agron. 2006, 51, 31-33.

25. Hunt, R. Plant Growth Analysis; Academic Division of Unwin Hyman Ltd.: Edward Arnold, UK, 1978; pp. 26-38.

26. Spancer, G.L.; Meade, G.P. Cane Sugar Hand Book, 9th ed.; John Wiley and Sons, Inc.: New York, NY, USA, 1963 ; p. 17.

27. Willey, R.W. Intercropping, its importance and research needs. Agron. J. 1979, 71, 115-119.

28. CIMMYT. From Agronomic Data to Farmers Recommendations: An Economics Training Manual; CIMMYT: Mexico City, Mexico, 1988.

29. Steel, R.G.D.; Torrie, J.H.; Dicky, D.A. Principles and Procedures of Statistics, A Biometrical Approach, 3rd ed.; McGraw Hill, Inc. Book Co.: New York, NY, USA, 1996. 
30. Li, X.; Mu, Y.; Cheng, Y.; Liu, X.; Nian, H. Effects of intercropping sugarcane and soybean on growth, rhizosphere soil microbes, nitrogen and phosphorus availability. Acta Physiol. Plant. 2013, 35, 1113-1119. [CrossRef]

31. Yang, W.; Li, Z.; Wang, J.; Wu, P.; Zhang, Y. Crop yield, nitrogen acquisition and sugarcane quality as affected by interspecific competition and nitrogen application. Field Crops Res. 2013, 146, 44-50. [CrossRef]

32. Mendoza, T.C. Light interception and total biomass productivity in sugarcane intercropping. Philipp. J. Crop Sci. 1986, 11, 181-187.

33. Gill, M.B. Physio-Agronomic Studies on Flat Versus Pit Plantation of Autumn and Spring Sugarcane (Saccharum officinarum L.). Ph.D. Thesis, Department of Agronomy, University of Agriculture, Faisalabad, Pakistan, 1995; pp. 41-89.

34. Ahmad, I. Bio-Economic Efficiency of Spring-Planted Sugarcane as Influenced by Spatial Arrangement and Nutrient Management. Ph.D. Thesis, Department of Agronomy, University of Agriculture, Faisalabad, Pakistan, 2002.

35. Pammenter, N.W.; Allison, J.C.S. Effects of treatments potentially influencing the supply of assimilate on its partitioning in sugarcane. Exp. Bot. 2002, 53, 123-129. [CrossRef]

36. Ahmad, R. Studies on Geometry of Planting Autumn Sugarcane Facilitating Intercropping of Wheat and Berseem. Master's Thesis, Department of Agronomy, University of Agriculture, Faisalabad, Pakistan, 1982.

37. Bukhtiar, B.A.; Muhammad, G. Feasibility of companion cropping with autumn planted cane. Pak. J. Agric. Res. 1988, 9, 294-299.

38. Khan, A.A.; Khan, M.A.; Khan, Q. Economic analysis of sugarcane (Saccharum officinarum L.) intercropping with canola (Brassica napus L.). Pak. J. Agric. Sci. 2012, 49, 589-592.

39. Roodagi, L.I.; Itnal, C.J.; Karabantanal, S.S.; Rachappa, V. Influence of planting systems and intercross on sugarcane tillering and yield. Indian Sugar 2001, 51, 159-163.

40. Chogatapur, S.V.; Deepa, G.S.; Chandranath, H.T. Review on Intercropping in Sugarcane (Saccharum officinarum L.). Int. J. Pure Appl. Biosci. 2017, 5, 319-323. [CrossRef]

41. Chattha, M.U. Studies on Growth, Yield and Quality of Sugarcane (Saccharum officinarum L.) under Different Planting Techniques, Irrigation Methods, Water Levels and Mulch Types. Ph.D. Thesis, Department of Agronomy, University of Agriculture, Faisalabad, Pakistan, 2007.

42. Gascho, G.T.; Shih, S.F. Cultural methods to increase sucrose and energy yield of sugarcane. Agron. J. 1981, 73, 999-1003. [CrossRef]

43. Domini, M.E.; Plana, R. Effect of planting density on sugarcane stalk growth and yield. Cultiaos Trop. 1989, 11, $67-73$.

44. Raskar, B.S.; Bhoi, P.G. Response of sugarcane to planting materials, intra-row spacings and fertilizer levels under drip irrigation. Indian Sugar J. 2003, 53, 685-690.

45. Aziz, K. Ratooning Potential of Autumn Sugarcane as Affected by Pit and Flat Planting. Master's Thesis, Department of Agronomy, University of Agriculture, Faisalabad, Pakistan, 1991.

46. Nazir, M.S.; Jabbar, A.; Ahmad, I.; Nawaz, S.; Bhatti, I.H. Production Potential and Economics of Intercropping in Autumn-Planted Sugarcane. Int. J. Agric. Biol. 2001, 4, 140-142.

47. Fareed, G. Effect of Associated Culture and Planting Geometry on the Yield and Quality of Autumn Sugarcane. Master's Thesis, Department of Agronomy, University of Agriculture, Faisalabad, Pakistan, 1990.

48. Kumar, S.; Angiras, N.N.; Singh, R. Effect of planting and weed control methods on weed growth and seed yield of Black gram. Indian J. Weed Sci. 2006, 38, 73-76.

49. Chattha, M.U.; Ali, A.; Bilal, M. Influence of planting techniques on growth and yield of spring planted sugarcane (Saccharum officinarum L.). Pak. J. Agric. Sci. 2007, 44, 452-455.

50. Devi, C.; Rao, K.L.; Raju, D.V.M. The effect of row spacing and nitrogen on yield and quality of early maturing sugarcane cultivars. Indian Sugar 1990, 40, 541-544.

51. Bhatti, I.H. Agro-Physiological Studies on Sesame-Legume Intercropping Systems in Different Geometric Arrangements. Ph.D. Thesis, Department of Agronomy, University of Agriculture, Faisalabad, Pakistan, 2005.

52. Patrick, M.C.; Gardner, J.C.; Schatz, B.G.; Zwinger, S.W.; Guldan, S.J. Grain yield and weed biomass of wheat-lentil intercrop. Agron. J. 1995, 87, 574-579. 
53. Saleem, K. Effect on Some Legume and Non-Legume Associated Cultures on Growth and Yield of Lentil. Master's Thesis, Department of Agronomy, University of Agriculture, Faisalabad, Pakistan, 1991.

54. Ehsanullah. Agro-Economic Studies on Various Sugarcane Based Intercropping Systems. Ph.D. Thesis, Department of Agronomy, University of Agriculture, Faisalabad, Pakistan, 1995.

(C) 2020 by the authors. Licensee MDPI, Basel, Switzerland. This article is an open access article distributed under the terms and conditions of the Creative Commons Attribution (CC BY) license (http://creativecommons.org/licenses/by/4.0/). 